\title{
Review of measures for improved energy efficiency in production-related processes in the aluminium industry - From electrolysis to recycling
}

J oakim Haraldsson and Maria J ohansson

The self-archived postprint version of this journal article is available at Linköping University Institutional Repository (DiVA):

http:// urn.kb.se/ resolve?urn=urn:nbn:se:liu:diva-148404

N.B.: When citing this work, cite the original publication.

Haraldsson, J., J ohansson, M., (2018), Review of measures for improved energy efficiency in production-related processes in the aluminium industry - From electrolysis to recycling, Renewable \& sustainable energy reviews, 93, 525-548. https:// doi.org/ 10.1016/j.rser.2018.05.043

Original publication available at:

https:// doi.org/ 10.1016/j.rser.2018.05.043

Copyright: Elsevier

http:// www.elsevier.com/

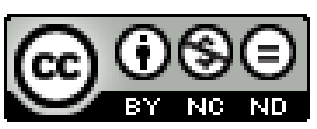




\title{
Review of measures for improved energy efficiency in production-related processes in the aluminium industry - From electrolysis to recycling
}

\author{
Joakim Haraldsson ${ }^{\mathrm{a},}{ }^{,}$, Maria T. Johansson ${ }^{\mathrm{a}}$ \\ a Division of Energy Systems, Department of Management and Engineering, Linköping University, \\ SE-581 83 Linköping, Sweden \\ * Corresponding author \\ E-mail addresses: joakim.haraldsson@liu.se (Joakim Haraldsson), maria.johansson@liu.se (Maria T. \\ Johansson
}

\section{ABSTRACT}

The aluminium industry is facing a challenge in meeting the goal of halved greenhouse gas emissions by 2050, while the demand for aluminium is estimated to increase 2-3 times by the same year. Energy efficiency will play an important part in achieving the goal. The paper's aim was to investigate possible production-related energy efficiency measures in the aluminium industry. Mining of bauxite and production of alumina from bauxite are not included in the study. In total, 52 measures were identified through a literature review. Electrolysis in primary aluminium production, recycling and general measures constituted the majority of the 52 measures. This can be explained by the high energy intensity of electrolysis, the relatively wide applicability of the general measures and the fact that all aluminium passes through either electrolysis or recycling. Electrolysis shows a higher number of emerging/novel measures compared to the other processes, which can also be explained by its high energy intensity. Processing aluminium with extrusion, rolling, casting (shape-casting and casting of ingots, slabs and billets), heat treatment and anodising will also benefit from energy efficiency. However, these processes showed relatively fewer measures, which might be explained by the fact that to some extent, these processes are not as energy demanding compared, for example, to electrolysis. In many cases, the presented measures can be combined, which implies that the best practice should be to combine the measures. There may also be a future prospect of achieving carbon-neutral and coal-independent electrolysis. Secondary aluminium production will be increasingly important for meeting the increasing demand for aluminium with respect to environmental and economic concerns and strengthened competitiveness. Focusing on increased production capacity, recovery yields and energy efficiency in secondary production will be pivotal. Further research and development will be required for those measures designated as novel or emerging.

Keywords: Aluminum industry, Aluminum production, Energy efficiency, Electrolysis, Recycling, Efficiency measures

\section{Nomenclature}

$A C D$

GHG
Anode-cathode distance

Greenhouse gas 
Onsite energy demand

PFC

Tacit energy demand
Energy used within the facility, excluding energy needed for generation/production and transmission/transportation of the electricity and fuel used

Perfluorocarbons, a group of powerful GHGs

Combination of the onsite energy demand, the process energy needed for production and transportation/transmission of the energy sources and the inherent energy in the fuels used as materials

\section{Introduction}

The aluminium industry is facing a challenge. The global demand for aluminium is estimated to increase 2-3 times by the year 2050 [1, 2]. At the same time, the industry's total GHG emissions are targeted to be cut in half by the same year $[1,2]$. This implies that the GHG emissions per produced ton of aluminium need to be reduced by at least 75\% [1]. Energy efficiency cannot meet all of this reduction on its own [2], but it will play a part in achieving the goal.

The production of aluminium is an energy- and $\mathrm{CO}_{2}$-intensive process [2]. The refining of bauxite (aluminium ore) to alumina (aluminium oxide) and the reduction of alumina to metallic aluminium are the two most energy- and $\mathrm{CO}_{2}$-intensive processes in the production of aluminium products [2].

A lot of research has been conducted in regard to aluminium production in general. However, the majority of this research has not studied energy efficiency measures but rather has focused on production-related factors. In some scientific articles, energy efficiency issues are mentioned, but the main focus is on other things, e.g. development of a technology or computational model. Energy efficiency falls into the background in these articles. The reference documents for best available technology (BAT) from the European Commission (see e.g. [3-5]) have a main focus on environmental aspects and present only a few measures for reduced energy demand. Kermeli et al. [6] review 22 efficiency measures in aluminium production. However, they focus just on primary production, including alumina refining, aluminium electrolysis, anode production and ingot casting, and do not include measures for the subsequent processing into finished products or recycling. They also focus on currently available measures and do not present any innovative measures for future energy reductions. BCS [7] has a main focus on electrolysis and process heating operations and only provides a brief description of future prospects in other main production processes when it comes to energy efficiency. This implies that there is a lack of scientific reviews studying energy efficiency for the entire aluminium industry as well as studying energy efficiency measures that are under development and not currently available.

Therefore, the aim of this paper is to review the findings of published papers on energy efficiency measures ${ }^{1}$ in the aluminium industry. The paper is limited to electrolysis of aluminium oxide (alumina) to aluminium, secondary aluminium production (recycling) and the most common production processes for processing of aluminium. Mining of bauxite and production of alumina from bauxite are not included in the review. The paper will include measures that are currently

\footnotetext{
${ }^{1}$ In this paper, an energy efficiency measure is defined as a technical measure that reduces the energy demand for producing one unit of product, e.g. one ton of aluminium. This implies that even if the measure reduces the energy need for producing one unit of product, the total energy demand can increase if the total production increases.
} 
available and innovative measures that are under development. However, the paper does not claim to present an exhaustive description of all possible measures but will focus on energy efficiency measures specific to the aluminium industry. This means that the article will mainly focus on the production-related processes.

Figure 1 shows a schematic supply chain for the production of aluminium products. The production processes within the dotted lines are studied in this paper. In addition, the surface treatment process called anodic oxidation and heat treatment are also included in the review, but they are not shown in Figure 1. 


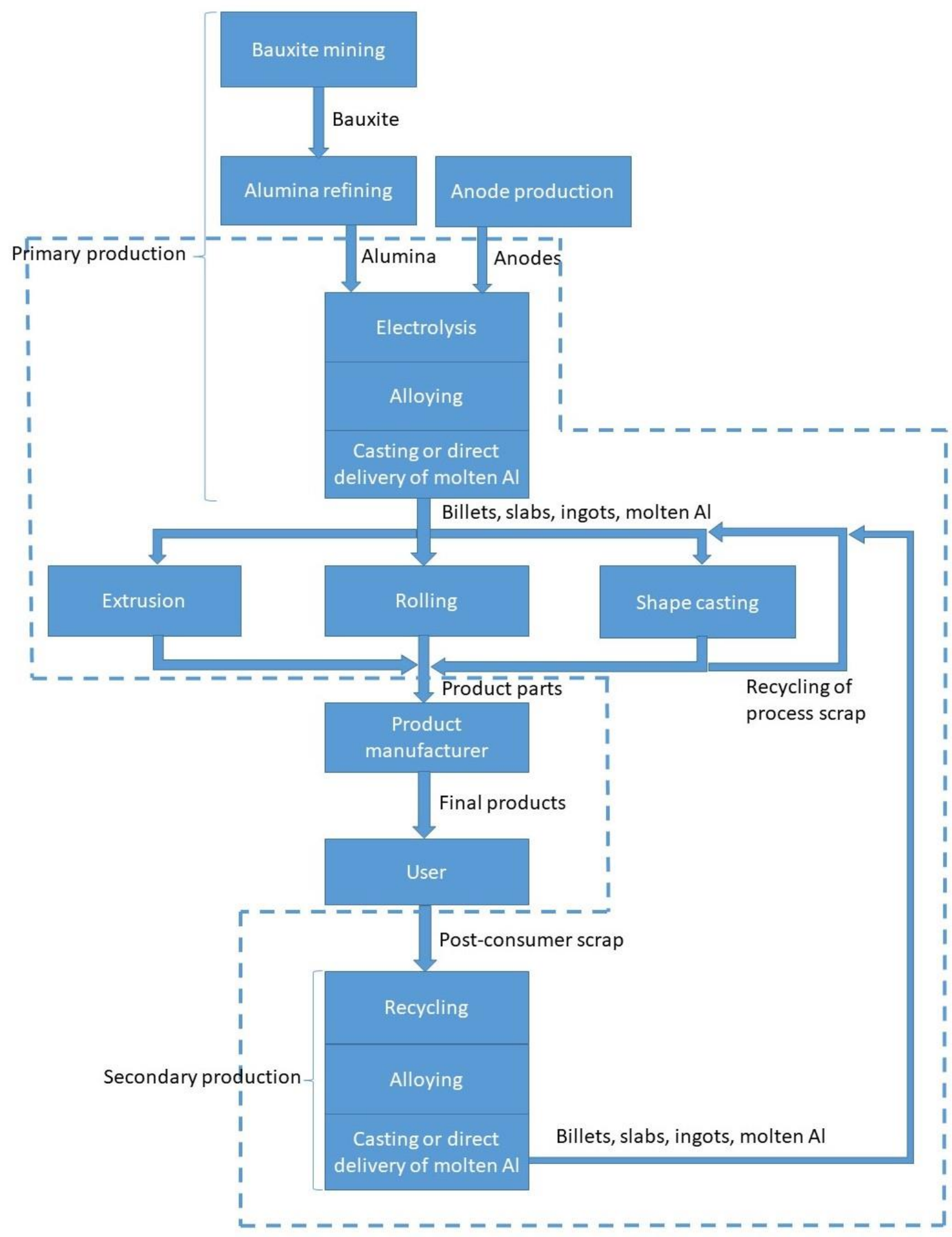

Figure $1 \mathrm{~A}$ schematic picture of the supply chain for production of aluminium products.

\section{Literature search and classification}

The work in this review can be divided into two parts: (1) an unsystematic part and (2) a systematic part. The first part was characterised by probing with a wide range of search strings based on 
keywords related to the topic. Some of the references found gave inspiration for further search strings. In some cases, literature from the reference lists of the references found were included in the review. The starting point was the European Commission's reference documents for BAT. In particular, the documents regarding non-ferrous metals industries [3], the smitheries and foundries industry [4] and surface treatment of metals and plastics [5] were used. These documents presented a number of efficiency measures and gave some understanding of the field that was helpful for the continued work with the review.

In the second part, a more systematic search for literature was performed. Figure 2 shows a graphical representation of the search process, the search strings used and their results. The words were searched for in titles, keywords and abstracts in the database Scopus. The searches were first limited to the past ten years (2007-2016) and to references written in English or Swedish. The searches were further limited to sources that seemed relevant by reading the titles and abstracts and to sources available in full text through the Linköping University library. Finally, these sources were read through, and the ones containing relevant information were included in the review. 


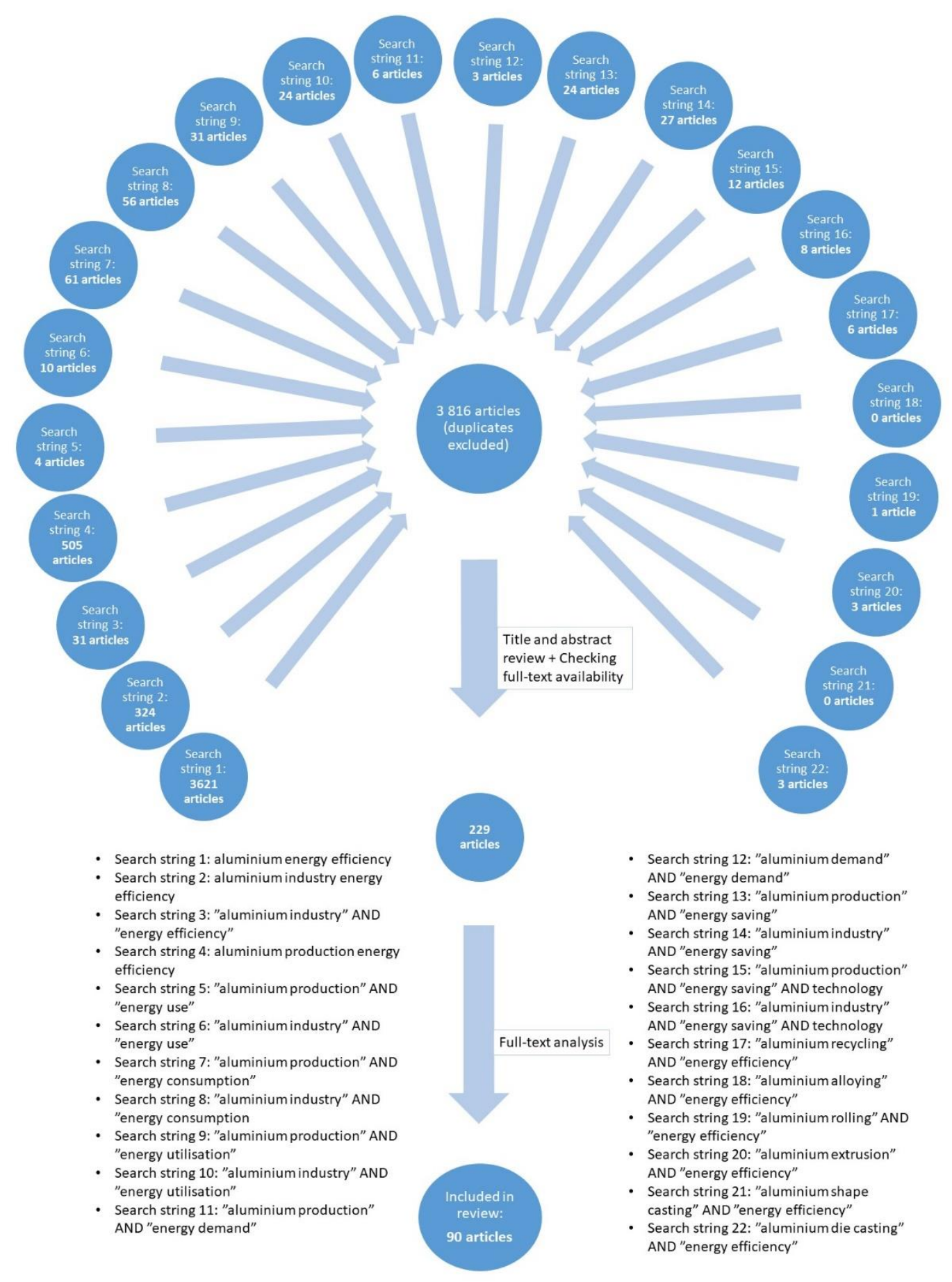

Figure 2 Graphical representation of the systematic search process.

In some cases, relevant energy efficiency measures were identified through the above search process, but the sources did not provide sufficient information about the measures. In these cases, further searches for information were conducted for those specific measures. In this case, the search strings used were based on the name or description of the measures. The searches were mainly conducted in the Scopus database, but in some cases, Google Scholar and Linköping University library's UniSearch (based on EBSCOhost) were also used. 
In total, 111 scientific references and 6 references from organisations and companies were included in the review. Ninety of the scientific references were found in the second part of the search process, but it is worth noting that some were found in the first part as well.

\section{Aluminium industry}

This chapter will provide a basic understanding of the production processes studied in this article. Some of the processes are illustrated below, but illustrations for the other processes can be found in e.g. [138].

\subsection{Electrolysis and alloying}

Primary aluminium is produced from aluminium oxide (alumina), and the major process for achieving this is the electrolytic process called the Hall-Héroult process [8]. An electrical reduction line is formed by connecting several electrolysis cells in series [3]. Figure 3 shows a schematic drawing of an electrolysis cell.

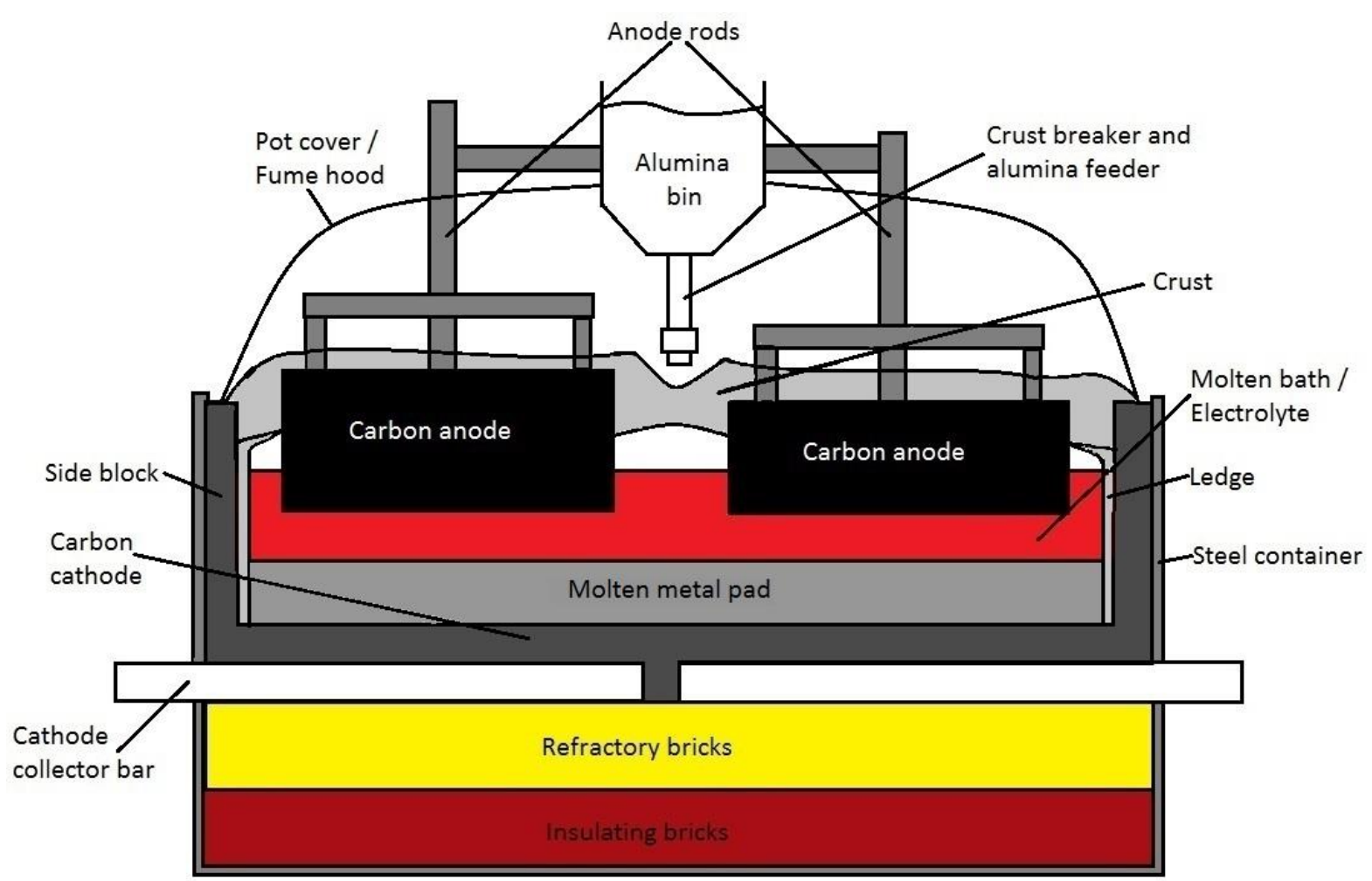

Figure 3 Schematic drawing of an electrolysis cell for primary aluminium production. Based on [7, 9].

The carbon anodes are continuously consumed during the electrolysis as the carbon combines with the oxygen in the alumina to form carbon dioxide and carbon monoxide [3]. A part of the energy needed for the cell operation is supplied by the carbon anodes [7]. The cathode is not consumed but deteriorates over time and has to be replaced after four to eight years, because of cracking, swelling and erosion [3].

Søderberg and prebaked are the two main types of electrolytic cells [3]. The Søderberg cells use a continuous anode, which is regenerated through the addition of carbon material at the top and is baked in-situ [3]. Prebaked cells use multiple anodes, which are manufactured in separate anode 
plants and need to be changed when approximately $80 \%$ is consumed [3]. In a modern cell, the anode needs to be changed after about four weeks [7]. As of 2013, there are only prebaked cells of the point feeder type (PFPB) in operation in Europe [3]. Figure 3 shows a PFPB cell.

The world average energy use for only the electrolysis cell is $13.4 \mathrm{kWh} / \mathrm{kg}$ Al produced [10]. If rectifiers and other cell auxiliaries, such as pollution control equipment, are included, the world average rises to $14.2 \mathrm{kWh} / \mathrm{kg}$ [10]. The energy cost can amount to as much as $50 \%$ of the production costs in the electrolysis [3].

Holding furnaces of either an induction or reverberatory type are used for storing the molten aluminium from the electrolysis and for adding alloying metals and additions to refine the grain of the metal [3]. Primary aluminium sites melt internal and bought scrap, which should be free from substances such as paint, plastics and oil [3]. The scrap is either melted separately before adding molten metal or is added to molten metal [3].

\subsection{Recycling and alloying}

Scrap melting is used to produce secondary aluminium. There is a variety of raw materials and hence a variety of furnaces used for melting the aluminium [3].

The first step is to sort the raw materials into wrought alloys and cast alloys [3]. Reverberatory furnaces are used for remelting the majority of wrought alloy scrap [3]. Rotary drum furnaces (sometimes tiltable) are mostly used for remelting cast alloys [3]. Sorting the scrap into specific alloy types for production of the desired alloys is done to minimise reprocessing [3]. The type and composition of the raw materials and the required product quality are major factors determining suitable treatment processes, furnace type and other process steps [3].

Secondary production of aluminium uses $0.56-2.5 \mathrm{kWh} / \mathrm{kg}$ Al where recycling of scrap with lower quality commonly uses more energy [3], although to produce secondary aluminium requires only $5 \%$ of the energy used for primary aluminium production $[3,8]$. However, this value depends on the recycling technology used [8].

Alloying additions can be made either directly to a casting system or via a transfer system into a holding furnace [3]. Either a holding furnace or an in-line reactor is used to refine the metal by removing gases and other metals [3].

\subsection{Generation of skimmings, dross and salt slag}

Skimmings, dross and salt slag are by-products of the aluminium industry [3]. Skimmings and dross are generated in the holding and treatment processes in both primary and secondary aluminium production [3]. Salt slag is generated in secondary aluminium production, generally from rotary furnaces, where a salt flux is used to reduce oxidation, promote removal of impurities and increase yield and thermal efficiency [3]. Dross can be split into white dross and black dross [11, 12]. Skimmings, dross and salt slag contain metallic aluminium, alumina and salts to varying degrees [1113].

\subsection{Casting}

Vertical direct chill casting machines with water-cooled metal moulds are used in the casting of ingots, slabs and billets in both primary and secondary production [3]. Horizontal direct chill casting 
can also be used for billets and slabs of smaller cross sections in primary production [3]. Static or continuously moving metal moulds are methods which can be used in primary production [3]. In secondary production, a variety of smaller ingots is cast in moulds, and these are used, for example to supply the casting industry [3].

The basic idea of shape casting is pouring or injecting molten aluminium alloys, typically remelted in a furnace, into moulds with one or several cavities of the desired shape [7]. There are several different shape-casting technologies; the important ones are described in Table 1.

Table 1 Description of the different shape-casting methods. Adapted from BCS [7].

\begin{tabular}{|l|l|}
\hline Casting method & Description \\
\hline Pressure die casting & $\begin{array}{l}\text { The use of water-cooled steel dies in which the metal is injected at } \\
\text { pressure up to about 70 MPa. }\end{array}$ \\
\hline Green sand casting & $\begin{array}{l}\text { The use of moulds which are produced by blending sand, binders and } \\
\text { moister. }\end{array}$ \\
\hline Dry sand casting & $\begin{array}{l}\text { Finished moulds are produced by coating the sand particles with air } \\
\text { or thermal setting chemicals. }\end{array}$ \\
\hline Permanent mould casting & $\begin{array}{l}\text { Molten metal is introduced by gravity or counter-gravity means into } \\
\text { iron or steel moulds. }\end{array}$ \\
\hline Investment casting & $\begin{array}{l}\text { The moulds are produced from ceramic slurries by repetitive } \\
\text { immersion of low-temperature melting pattern materials. The } \\
\text { ceramic is hardened by a drying process after which the pattern } \\
\text { material is removed by heating the mould to a temperature which } \\
\text { eliminates the pattern material. Before pouring the metal, the mould } \\
\text { is typically preheated. The mould may also be filled under vacuum. }\end{array}$ \\
\hline Plaster casting & $\begin{array}{l}\text { The production of thicker sections and larger parts, for which } \\
\text { investment casting is less suited. }\end{array}$ \\
\hline
\end{tabular}

\subsection{Extrusion}

In extrusion, an elongated shape with a consistent cross section is formed by forcing a preheated billet through a steel die by hydraulic pressure [7]. Virtually all modern extrusion presses extrude horizontally [7]. The product design, desired mechanical characteristics and alloy determine which temperature the billet is preheated to, which is typically somewhere between $450{ }^{\circ} \mathrm{C}$ and $550{ }^{\circ} \mathrm{C}[7]$.

There is both a direct and an indirect extrusion process with the difference that the billet is the moving part in direct extrusion, whereas the die is the moving part in indirect extrusion [7], as shown in Figure 4. A metal loss occurs in direct extrusion, since the billet surface is retained in the extrusion container and does not become a part of the product [7]. This implies that removing the skin layer by scalping is not needed [7]. However, scalping is required for indirect extrusion, since the billet surface becomes a part of the product [7]. 


\section{Direct extrusion}

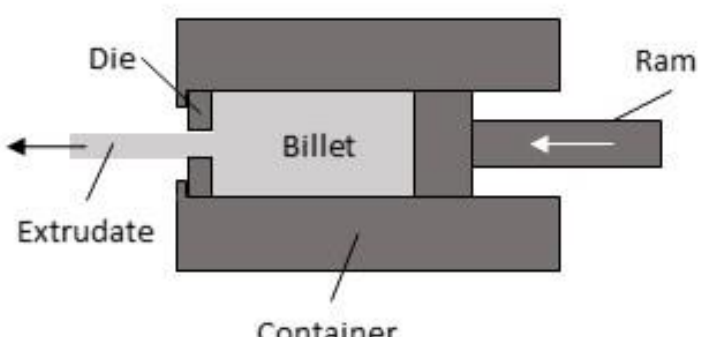

Container

\section{$\underline{\text { Indirect extrusion }}$}

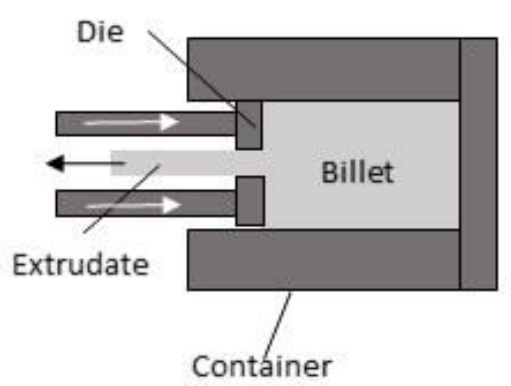

Figure 4 Schematic drawing of direct and indirect extrusion. Based on [138].

\subsection{Rolling}

In rolling, the slab is passed between counter-rotating steel rolls multiple times to reduce the slab's thickness [7], as shown in Figure 5. When producing rolled products, the slab typically passes through both a hot rolling step and a cold rolling step [7]. In hot rolling, the metal is preheated in a furnace to a temperature between $400{ }^{\circ} \mathrm{C}$ and $500{ }^{\circ} \mathrm{C}$, depending on the alloy [7]. The cold rolling step is typically conducted after the hot rolling step and takes place at room temperature [7].

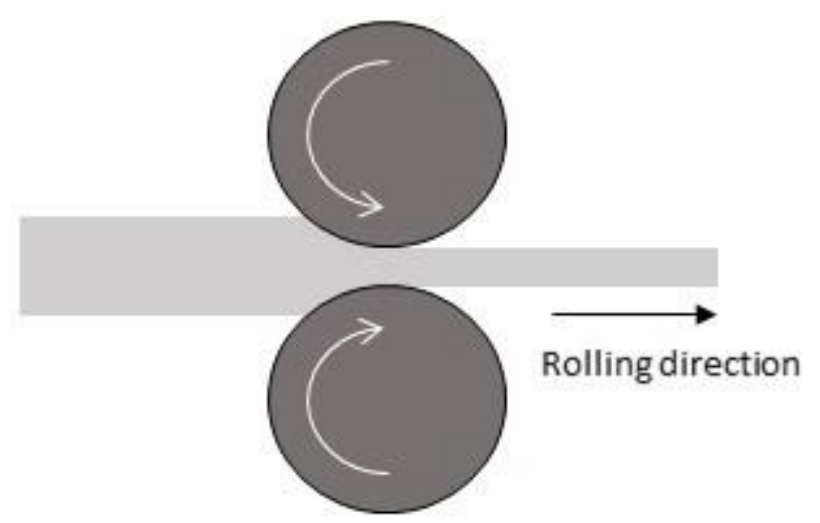

Figure 5 Schematic drawing of the rolling process. Based on [138].

The ends and edges of the metal need to be cut off during several occasions of the rolling processing operations [7]. Additionally, the top layer of the slab surfaces needs to be scalped off for quality and uniformity reasons [7]. Heat treatments in furnaces, e.g. homogenisation, are used in rolling plants [7]. Homogenisation can be either a separate step or an integrated with the preheating prior to hot rolling [7].

\subsection{Heat treatment and surface treatment}

Heat treatments in furnaces are used to alter physical and mechanical properties of the metal [14]. This is to make the metal more suitable for certain applications or to ease the manufacturing, for example, regarding formability or machining [14]. There is an international designation system used to state which heat treatment has been used, which includes five main categories ( $F, O, H, W$ and $T$ ) [134]. For the main category $\mathrm{T}$, there are ten main subcategories (T1-T10) with further 
subcategories [134]. For a description of the different main categories and subcategories see for example [134].

Anodic oxidation (anodising) is an electrolytic surface treatment process producing an oxide layer by enhancing the metal's natural ability to oxidise, which enhances the properties of the metal surface [5]. Sulphuric acid electrolyte is used in $90 \%$ of the cases to anodise aluminium [5]. Phosphoric acid, chromic acid, sulphuric/salicylic acids and sulphuric/oxalic acid electrolytes are examples of other process solution types [5]. Pretreatment processes may be needed, for example for cleaning purposes [5].

There is normally a sealing process following the sulphuric acid anodising, which further improves the surface's properties [5]. Hot or cold processes can be used for the sealing [5]. In hot sealing, hydration of the aluminium oxide to boehmite is used to close the pores in the oxide layer [5]. Hot or boiling (minimum $95-96^{\circ} \mathrm{C}$ ) deionised water is used for the sealing process [5]. The same effect is achieved by using steam for the sealing [5].

\section{Opportunities for improved energy efficiency}

Table 2 shows the number of publications presenting measures for improved energy efficiency in the production processes studied. The focus is on the publications found during the second part of the literature search, i.e., the structured approach.

Table 2 Number of publications presenting measures for improved energy efficiency in the production processes studied. The table only includes the publications found during the structured literature search.

\begin{tabular}{|l|l|l|l|l|l|l|l|l|l|l|l|}
\hline Year & 2007 & 2008 & 2009 & 2010 & 2011 & 2012 & 2013 & 2014 & 2015 & 2016 & Total \\
\hline $\begin{array}{l}\text { General } \\
\text { measures }\end{array}$ & 2 & 0 & 2 & 2 & 4 & 4 & 1 & 1 & $6^{1}$ & 3 & 25 \\
\hline Electrolysis & 0 & 5 & 1 & 4 & 10 & 2 & 9 & $10^{2}$ & $2^{1}$ & 6 & 49 \\
\hline Recycling & 0 & 0 & 1 & 1 & 1 & 0 & 1 & $2^{2}$ & 1 & 1 & 8 \\
\hline $\begin{array}{l}\text { Metal } \\
\text { processing }\end{array}$ & & & & & & & & & & & \\
\hline - Extrusion & 0 & 0 & 0 & 0 & 0 & 0 & 0 & 0 & 0 & 0 & 0 \\
\hline - Rolling & 0 & 0 & 0 & 0 & 0 & 0 & 1 & 1 & 0 & 0 & 2 \\
\hline - Casting & 0 & 0 & 0 & 0 & 2 & 1 & 0 & 0 & 1 & 0 & 4 \\
\hline - Anodising & 0 & 0 & 0 & 0 & 0 & 0 & 0 & 0 & 0 & 0 & 0 \\
\hline $\begin{array}{l}- \text { Heat } \\
\text { treatment }\end{array}$ & 0 & 0 & 0 & 0 & 1 & 0 & 0 & 3 & 0 & 0 & 4 \\
\hline Total & 2 & 5 & 4 & 7 & 18 & 7 & 12 & 16 & 9 & 10 & 90 \\
\hline
\end{tabular}

${ }^{1}$ One article repeats, being counted in the total for each process. But it is only counted once in the total for the year.

${ }^{2}$ One article repeats, being counted in the total for each process. But it is only counted once in the total for the year.

The following sections will first present energy efficiency measures which are commercially available for each of the production processes. Then, in the last section, emerging or novel technologies, which are not commercially available yet, will be presented.

\subsection{General measures}

\subsubsection{Heat recovery and heat loss reduction}

Several production processes in the aluminium industry use heat and give rise to considerable amounts of excess heat. These processes include but are not limited to: 
- Electrolysis cells for primary production

- Melting furnaces for secondary production, remelting and shape casting

- Holding furnaces

- Furnaces for heat treatment and homogenisation

- Preheating prior to hot rolling and extrusion

- Process tanks for anodising

Excess heat from the exhaust gas is probably the easiest to recover, since the exhaust gas is already channelled into duct layouts and chimneys [15]. Excess heat from the gas exhaust from electrolysis cells can be recovered through, for example, heat exchangers $[16,17]$. Excess heat can be used for space heating within the production site [18], district heating, (district) cooling through absorption, preheating/drying of raw materials, power generation with an organic Rankine cycle [16, 18], a Kalina cycle or a heat engine [18] or the desalination of water [16-18]. The temperature and medium of the excess heat determine the technology to be used for heat recovery (see for example [135]).

A novel technology is the reduction cell structure with a lava thermo-exchanger, which can control the temperature distribution condition of the cell [19]. At the same time, the technology can reclaim heat with a high efficiency, and the heat can be used for other applications [19]. Reduction cells with lava thermo-exchangers could have the possibility for widespread application in the future [19].

Another technology is the two-phase thermosyphon technology, which uses a gravity-assisted wickless heat pipe to transport heat by using evaporation and condensation [20]. For low- or medium-temperature excess heat recovery, in which self-controlling capability, high reliability and high efficiency are important, two-phase thermosyphons may be especially attractive [20]. Twophase thermosyphon technology has not yet been used in large-scale industrial applications, but it has shown promising potential for excess heat recovery [20].

In furnaces, heat losses can be reduced by using better refractory lining/insulating material [6, 2123], by using appropriate wall thickness [23] and by covering open wells [24, 25]. Heat can be recovered by using heat exchangers and by using regenerative burners and recuperative burners [24-26]. Furnaces with regenerative burners use fluidised beds to preheat the furnace combustion air with the exhaust gases [24, 25], which can save up to $40 \%$ of the fuel need [21, 24]. Recuperators are counterflow heat exchangers which can be used on a furnace to preheat the combustion air, metal charge or both with excess heat from the exhaust gases [23]. This can increase the furnace efficiency [23]. Heat exchangers on the exhaust gas from large furnaces can save about $23 \%$ of fuel on average [21]. Better insulation material can reduce the energy use by $2-5 \%$ [6]. Preheating the combustion air with recovered heat from the exhaust gases will reduce the heat losses and the fuel need for reaching the process temperature, for a $10-30 \%$ reduction in energy need [6].

A technology called preheat hearths can be added to the furnace; it uses heat from the exhaust gases and some radiant absorption from the burners to preheat ingots [21]. A 15\% saving in fuel need can be achieved by the preheating [21].

In casting facilities, excess heat from induction furnace cooling systems can be used for drying raw materials, space heating and hot water [4]. Excess heat from copula furnace off-gases can be used for space heating, hot water or electricity production in a steam boiler [4]. Excess heat can also be 
used for preheating scrap or metal charge, preheating the air supply to a furnace, electricity generation and absorption refrigeration [26].

Reducing the amount of extracted warm air from anodising process tanks will reduce heat losses by evaporation [5]. This can be done by using lids on the tanks, creating an airflow over the processing bath surface or enclosing the plating line [5]. Heat from certain process steps may be reused in other process steps [5]. Heat losses can be reduced by better insulating the process tanks [5]. The solution surface can be insulated by using floating insulation, although this is not applicable if the insulation interferes with the treatment [5]. The energy input can be minimised by controlling the temperature for a process where there is a range of possible temperatures [5]. The operating temperature may be lowered/increased for processes needing heating/cooling [5].

\subsubsection{Stirring system or metal pumping}

The temperature gradient between the top and bottom of a furnace can be reduced with the help of either stirring or metal pumping $[27,28]$. This can reduce the dross generation by as much as $25 \%$ $[27,28]$. Both energy use and $\mathrm{CO}_{2}$ emissions associated with the energy use are reduced [28]. An energy saving of $10-20 \%$ and an increase in energy efficiency of $15-35 \%$ can be achieved with metal pumping in a reverberatory furnace [27]. Other benefits are improved refractory life [28], increased productivity [27] and improved alloy homogeneity [3, 27].

\subsubsection{Immersed furnace heaters}

Immersion heaters can adopt electrical or fire-tube heaters together with a refractory material housing to protect the heaters [29]. The technique is based on immersing the heater into the metal and the predominant heat transfer mechanism is conduction [29]. An immersed heater furnace has a thermal efficiency that is 2-3 three times higher than the thermal efficiency for an open fire burner furnace [29], and it can be as high as $97 \%$ [7]. This results from an improved heat transfer to the molten metal [29]. Up to about $66.7 \%$ of the gas demand can be saved with immersed heaters [29]. The fire-tube immersion heater is also more advantageous than its open flame equivalent when it comes to oxidation losses and skim production [29]. Enhanced mixing of the metal is also achieved due to the natural convection [29].

\subsubsection{Oxy-fuel combustion}

Increased energy efficiency can be achieved by combustion in pure oxygen [4, 26, 30], or so-called oxy-fuel combustion. An overall energy reduction of $50-60 \%$ has been demonstrated in an aluminium remelting furnace [30]. For a rotary furnace for casting applications, the energy saving may also be $50 \%$ [4]. However, there may be a risk of higher dross generation when using oxy-fuel combustion [31].

Oxy-fuel combustion is practical for melting aluminium, which requires a high specific melting rate [31]. However, for holding molten aluminium, oxy-fuel combustion is not the most economical technique, since a lower amount of heat is needed [31]. To hold molten aluminium, air-fuel combustion is better suited, since it can provide constant energy to the furnace [31]. Furnaces used for both melting and holding aluminium should be able to switch between oxy-fuel and air-fuel combustion to lower the energy usage and cost [31]. This will also help reduce the dross generation, which increases the yield [31]. There will also be metal quality improvements [31]. 


\subsubsection{Non-stationary flame burner}

In using a non-stationary flame burner, heat is transferred to the preferred areas of the furnace by directing the flame to those areas [31]. Higher firing rates are used in areas with a higher concentration of metal charge than in areas with less charge [31]. This results in both uniform heating and uniform melting by directing the flame to specific areas [31]. After the metal has been entirely melted, uniform heat transfer to the molten bath is achieved through continued movement of the flame [31]. The yield increases through reduced problems with oxidation losses, since no hot spots occur on the aluminium or the refractory material [31]. There will also be metal quality improvements [31].

An experiment showed a reduction of more than $25 \%$ in dross generation, compared to traditional air-fuel burners, when scrap was charged [31]. The specific melt rate increased by a factor of two and by $30 \%$, respectively, compared to traditional air-fuel and traditional oxy-fuel burners [31]. There was also a decrease in the energy use compared to traditional air-fuel burners [31].

\subsubsection{Furnace operation improvements}

A furnace's energy use can be reduced by implementing operational improvements, for example reducing the door opening time and the holding time [24]. Preheating the fuel-air mixture for the burners in a holding furnace to $500 \mathrm{~K}$ instead of supplying it at $300 \mathrm{~K}$ can also increase the energy utilisation efficiency from $34.55 \%$ to $37.14 \%$ [32]. An excess air coefficient of around 1.05 is recommended for optimal energy utilisation efficiency in a holding furnace [32].

Other factors to consider are:

- The use of an air-fuel control system to measure and optimise the flows of air and gas [33] to supply an optimal amount of excess air and thus the appropriate air-fuel ratio. A 5-15\% energy reduction can be achieved [6].

- The use of a temperature control system with the temperature set point not being too high [33].

- The use of stirring [33].

- Not making the depth of the metal bath too large, which could also be overcome with stirring [33].

- The length-to-width ratio of the furnace affects the energy intensity, and a round or square furnace is better from an energy perspective than a rectangular furnace [33].

- A higher space from the metal surface to the furnace roof is better [33].

- Automatic charging of metal to the furnace [33].

- Only charge molten metal into furnaces designed for molten metal delivery [33].

- The use of a furnace pressure system to ensure a slightly positive pressure [33]. This leads to avoided heat losses due to air infiltration and an energy saving of 5-10\% [6].

- The amount of heat transferred to the metal can be increased by adjusting the burners for efficient operation [6]. The energy use can be reduced by $5-10 \%$, and there will also be an increase in productivity [6].

- Energy losses can be reduced by improved control systems, especially at low throughput, for an estimated energy saving of 5-10\% [6]. 


\subsubsection{Gas purging system}

Gas purging systems can be used during several stages of the metal production, for example alloying, metal cleaning and melting [34]. The technology is based on using several porous plugs, shown in Figure 6, to blow inert or reaction gases into the melt [34]. The benefits include energy and production time savings, higher productivity, homogenous temperature distribution and improved metal grades, maintenance and refractory service life [34]. A case study showed a melting rate increased by $33-38 \%$, a $15 \%$ reduced energy use and yearly production increased by $16 \%$ at lower costs [34]. There was also a reduced metal loss through reduced metal combustion and lower dross formation, since the process temperature could be lowered through better insulation and less opening of the furnace door [34].

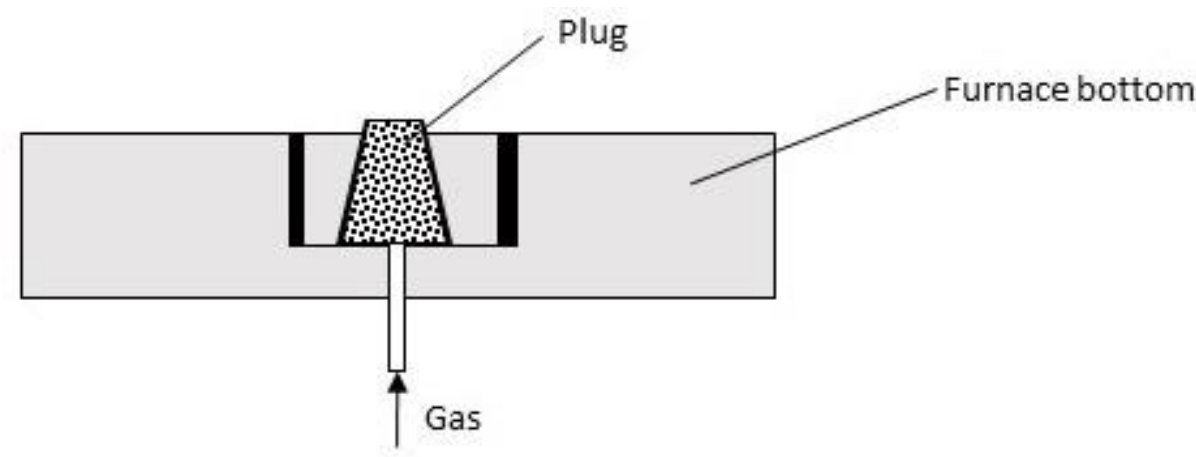

Figure 6 Simplified drawing of a purging plug. Based on [34, 136].

\subsubsection{Increased aluminium surface emissivity}

When melting aluminium shapes, such as ingots, it is common to utilise radiant heat [35]. The surface emissivity of an object, which equals the absorption coefficient, is one thing affecting the heat transfer rate by thermal radiation into or out from an object [35]. The radiant heat transfer to aluminium is inefficient, due to the very low absorption coefficient of aluminium [35]. However, the absorption coefficient can be increased by applying a dark surface coating to the aluminium [35]. An increase in the melting rate and a reduction in energy use occurs, due to increased radiant heat transfer [35]. Oxidation losses are expected to decrease, since there is less need for direct flame impingement [35]. An experiment showed a reduction of the energy use from $1.7 \mathrm{kWh} / \mathrm{kg}$ Al to $1.4 \mathrm{kWh} / \mathrm{kg} \mathrm{Al}$ [35], a reduction of about $18 \%$. No contamination of the aluminium from the coating could be seen in the experiment [35].

\subsubsection{Reduction of process scrap}

Process scrap, or yield losses, can originate from high purity and specification requirements, quality problems [7, 36], defects [1, 7], over-ordering, mismatches between batch and order volumes, subtractive processing, scalping and trimming during processing and start-up losses [36]. This implies that more material needs to be produced than ends up in the final product, which increases the total energy need per unit of the final product [36]. Additional energy is also needed for remelting the process scrap and thus bringing the metal back to production [1]. Reducing the generation of process scrap can provide both energy and economic benefits.

Yield losses can result in the embodied energy in the final products being up to 15 times higher than the energy needed to produce liquid metal [2]. On a global scale, $41 \%$ of the liquid aluminium 
produced is diverted as process scrap [2]. A 6\% reduction in total energy use and a $7 \%$ reduction in total $\mathrm{CO}_{2}$ emissions can be achieved by eliminating all process scrap [2].

\subsection{Electrolysis}

\subsubsection{Process performance improvements}

The process performance improvements in electrolysis can include:

- Automatic feeding of alumina at multiple points [3]

- Automatic anode effect suppression [3, 37, 38]

- The use of a computer-aided monitor and control system [3, 39], such as:

- Active cell databases [3].

- The Statistical Process Control (SPC) method [39].

- The combination of fuzzy theory, rough set and a genetic algorithm for fault diagnosis [40].

- A fuzzy controller combined with mathematical models to predict the process temperature [41]. An industrial application in $300 \mathrm{kA}$ prebake cells for two years showed [41]:

- An energy saving of about $0.6 \mathrm{kWh} / \mathrm{kg} \mathrm{Al}$ (from about 13.4 to about $12.8 \mathrm{kWh} / \mathrm{kg} \mathrm{Al})$.

- A voltage reduction of about $0.27 \mathrm{~V}$ (from about 4.17 to about $3.9 \mathrm{~V}$ ).

- A temperature reduction of about $7{ }^{\circ} \mathrm{C}$ (from about 958 to about $951{ }^{\circ} \mathrm{C}$ ).

- Systems based on Kalman filters, a state estimation method for dynamical systems [42].

In addition to the reduced energy usage, there are several environmental and operational benefits associated with improving the process performance $[3,37,39]$, including a reduction in GHG emissions $[3,37,43]$. Improvement of the cell control point-feeding systems of existing PFPB cells can reduce the electricity use by $0.2 \mathrm{kWh} / \mathrm{kg}$ Al for an investment cost of 100-150 Euro/ton Al [6].

Generally, there are three generations of process control systems for electrolysis cells [44].

Generation 1 is a reactive control system designed to bring the process back to its target settings by manipulating other variables [44]. As of 2014, almost all electrolysis cells in the world included control systems categorised as Generation 1 [44]. Generation 2 is designed to diagnose and remove root causes by employing corrective actions and avoiding the compensatory measures common to Generation 1 [44]. Only a few primary producers had adopted Generation 2 as of 2014, even though it has been available since 2007-2008 and can reduce energy use by $0.4 \mathrm{kWh} / \mathrm{kg} \mathrm{Al}$ [44]. However, the diagnosis and abnormality removal system for Generation 2 is mainly manual and provides little to no immediate feedback for the root causes [44]. Additionally, the alumina feeding control system does not take into account the dissolution rate of alumina in the electrolyte [44]. Generation 3 employs a more sophisticated control system than Generation 2 with the aim to diagnose the underlying variation both in each cell and in groups of cells and entire potlines [44]. Diagnosing and addressing root causes as well as preventing the cell from going out of control is achieved by energy and mass balancing strategies and advanced multivariate technologies [44]. Generation 3 was successfully tested in a smelter in 2014 and showed a $0.355 \mathrm{kWh} / \mathrm{kg}$ Al reduction in energy need compared to before the implementation of Generation 3 [44]. 


\subsubsection{Cell voltage noise reduction}

Three different types of voltage noise occur in the electrolysis cell. Bubble noise or fluctuating noise occurs due to the production of $\mathrm{CO}_{2}$ bubbles on the anodes as a necessary and inevitable part of the electrolysis process [45-48]. Short-circuiting noise or pulsating noise occurs due to a temporary shortening caused by molten metal splashing against the bottoms of the anodes [45-48]. Metal pad motion or wavy noise occurs due to vigorous metal movement in the cathode cavity, resulting in changes of the actual ACD [45-48].

Bubble noise is not a concern for cell operation and has little effect on the current efficiency and power demand of the electrolysis process [45-48]. Current efficiency is reduced and power demand is increased by both the anode short-circuiting noise and the metal pad roll noise [45-48]. Therefore, the control system should distinguish between the different noise types and only suppress the noise of the anode short-circuit and metal pad roll types as quickly as possible [45-48]. Another way to reduce the fluctuations due to the metal pad roll is to use novel structure cathodes (described below) [49].

\subsubsection{Ensure good anode quality}

Two aspects found in the literature will be mentioned here: crack-free anodes and coke quality. Cracks in the anodes are discontinuities in the material, which increases the electrical resistivity of the anodes and thus the energy use in the electrolysis [50]. Amrani et al. [50] present measures which the anode producer can use to minimise the number of cracks. However, these measures are outside the scope of this review. The anode overpotential may be increased by low-quality coke, which results in increased electricity demand [51]. Improved anode quality can help to reduce the number of anode effects [38]. The electrolysis plant should ensure that they use anodes with a minimal number of cracks and good coke quality.

\subsubsection{Anode preheating}

During the changing of the anodes, a layer of frozen electrolyte bath is immediately quenched on the bottom surface of the new, cold anodes [52]. Energy is required to melt the layer of frozen electrolyte, and productivity is reduced during the time it takes to melt it [52]. A disrupted bath motion around the new anodes and an uneven anode current distribution occurs until the layer is melted and is thought to increase the noise and reduce the current efficiency [52].

Preheating the bottom surface of the anodes to $480-510{ }^{\circ} \mathrm{C}$ before lowering them into the electrolyte bath can increase the current efficiency by $0.5-1 \%$ and can double the electrical current pick-up rate [52]. There is a potential energy saving of about $0.04 \mathrm{kWh} / \mathrm{kg} \mathrm{Al}$, which does not take the energy for preheating the anodes into account [52]. This is due to the fact that the anodes either can be delivered directly from the bake furnaces or can be heated by the excess heat from the electrolysis [52].

\subsubsection{Slotted or perforated anodes}

A gas bubble layer is produced on the bottom of the anodes due to the electrolysis reaction $[49,53]$. The discharge distance for the anode gas can be reduced by using anodes that are both slotted and perforated (as in Figure 7) [49] or perforated all the way from top to bottom [53]. This will decrease the penetration depth and the residence time for the anode gas in the molten bath as well as the thickness of the bubble layer $[49,53]$. In turn, this leads to reduced back reaction between the 
anode gases and the molten aluminium and thus increases the current efficiency [49, 53]. The reduced bubble layer thickness also results in reduced cell voltage $[49,53,54]$. Both the increased current efficiency and the reduced voltage result in a decrease of the power demand for the electrolysis $[49,53]$.

\section{Anodes with both slots and holes}
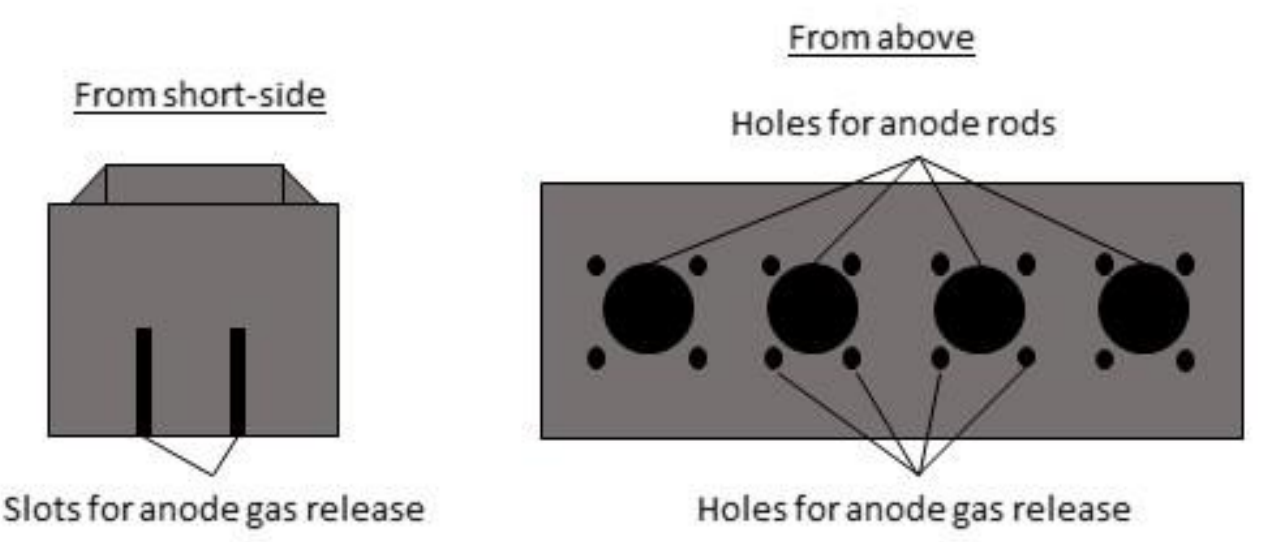

Figure 7 Anodes with both slots and holes. When the slotted part is consumed, the anodes gas escapes through the holes [49]. Based on [49].

The industry tests presented in Tian et al. [53] showed an average increase in current efficiency of $0.7 \%$ points and an average decrease in power demand of $0.781 \mathrm{kWh} / \mathrm{kg}$.

\subsubsection{Optimised anode rod assembly design}

The anode rod assembly design can be optimised through, for example, changing the rod dimensions and by improved welding technologies [55]. An energy saving in the electrolysis is achieved by a reduced voltage drop in the modified assemblies [55]. An experiment showed that the voltage drop reduction can be as high as $80 \mathrm{mV}$ [55]. However, an increase in the voltage drop was observed during the experiment, and the proven reduction was shown to be around $24 \mathrm{mV}$ [55]. The experiment did show an increase of the anode effect occurrence and the pot noise when using the tested assembly design [55].

\subsubsection{Graphitised cathode}

Changing the cathode material from anthracitic carbon to fully graphitised carbon can provide energy savings $[56,57]$ through a lower cathode voltage drop [57]. Fully graphitised carbon can also provide higher cathodic current densities [56] and larger electrical stability for the electrolysis [57]. However, the cathode lifetime drops by two to three years when using fully graphitised carbon, since this carbon has a lower wear resistance than other types [56].

\subsubsection{Novel structure cathodes}

Novel structure cathodes (NSC), in contrast to ordinary cathodes with plane surfaces, have surfaces with different shape arrangements $[54,58,59]$. Figure 8 shows two examples of NSC. The rectangular ridges can have either stepped sides or sloping sides [54]. NSC can save from 0.56 [54] 
up to $1 \mathrm{kWh} / \mathrm{kg} \mathrm{Al}$ and increase the current efficiency [58,59]. The lowered energy demand results from reduced $A C D$, which is possible due to weakened metal pad fluctuation $[54,58]$.

\section{Cylinder shapes}

From the side

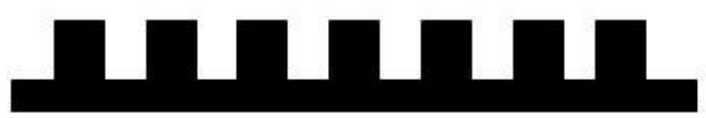

Fromabove

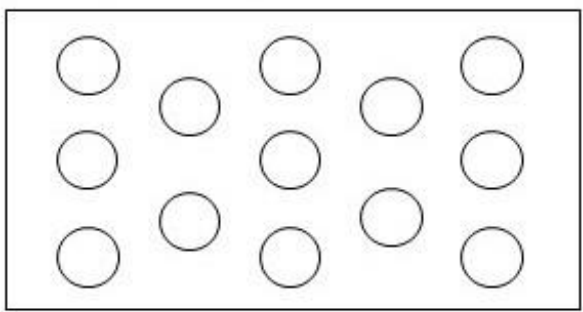

Rectangular ridges

From the side

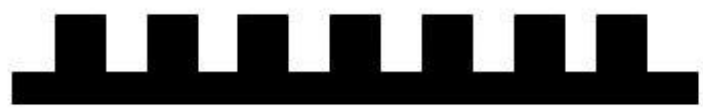

Fromabove

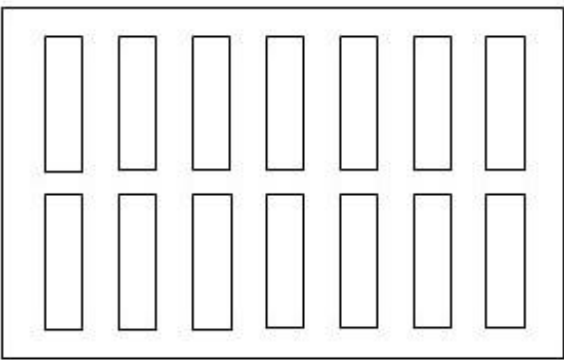

Figure 8 Two examples of novel structure cathodes. Based on [58, 59].

\subsubsection{Optimised cathode collector bar structure}

Optimising the cathode collector bar structure includes changing the collector bar's conductive structure as well as a suitable adjustment of the cathode carbon height and the collector bar size [60]. Additionally, adjustment to the cathode assembly's resistance distribution through optimisation of the assembly form of the cathode carbon and the collector bar can also be made [60]. A more vertical current flow into the cathode carbon, and thus a reduced horizontal flow, is achieved by these adjustments and yields high improvements in cell stability [60]. Industrial tests have shown an energy reduction of $0.738 \mathrm{kWh} / \mathrm{kg}$ Al and a $0.725 \%$ points improvement in the current efficiency [60]. Other advantages are simple implementation and low investment cost [60].

Other technologies which reduce the horizontal current flow and include changes in the collector bar structure are:

- The use of an electrically insulated region between the cathode and the collector bar [54].

- The use of a cathode design with bottom exit collector bar, which implies a change of the collector bar design and the cell exit location [54]. This technology is in the test phase [54].

- Electrically insulating the carbon block from the steel bloom by using heatproof concrete [61].

\subsubsection{Reduced cell ventilation}

The total electricity demand for the ventilation fans can be reduced by reducing the ventilation rate in the cell [62]. However, ventilation is important for the heat balance of the cell [62]. A reduced 
ventilation rate results in lower heat losses through the top of the cell, which can have an adverse effect on the operating conditions of the cell [62]. A way to maintain the same heat extraction through the ventilation and at the same time reduce the ventilation rate is to expose a larger part of the anode stubs to the ventilation airflow [62]. However, it is important to still have some anode cover close to the stubs to avoid oxygen from the air burning off the anodes [62].

There is a technology called distributed pot suction (DPS) system, which allows for the ventilation rate to be varied within a wide area [63]. This is achieved when the DPS system is combined with a specific thermal design of the superstructure and an overall improved gas capture efficiency [63]. Overall, the ventilation rate can be reduced without increased emission levels [63]. Due to the closeness to the point-feeder holes, the exhaust gas is delivered at higher temperatures, which is beneficial for a heat recovery system for producing electricity [63]. The exhaust gas concentration in general and the $\mathrm{CO}_{2}$ concentration specifically are also increased $[63,64]$. This has implications when designing new gas treatment plants [63] and can help to enable the potential for $\mathrm{CO}_{2}$ treatment [63, 64]. The special thermal design leads to reduced heat losses to the superstructure as well as to lower exposure to heat stress and thus to a longer lifetime for the equipment mounted on the superstructure [63]. An experiment showed a decrease in heat losses through the ventilation by $0.4 \mathrm{kWh} / \mathrm{kg}$ Al when using the DPS system [63]. However, higher heat losses from other parts of the superstructure likely lead to a smaller net effect [63]. The DPS system's suitability regarding, for example, mechanical stability, the effect of long-term heat exposure and clogging/deposits needs to be evaluated in long-term tests [64].

\subsubsection{Addition of lithium fluoride}

The most effective way to increase the conductivity of the electrolysis bath is by adding lithium fluoride (LiF) [54]. The voltage drop over the electrolysis cell can be reduced by about 3-5 mV/cm of ACD for every $1 \%$ of LiF addition [54].

\subsubsection{Current switch bypass}

Figure 9 shows a schematic drawing of an electrolysis cell with and without a current switch bypass. Parallel bypass-short circuit busbars are used at the bottom of each pot to allow for carrying out an overhaul of a single cell without interrupting other cells [65]. When stopping a cell, the potline current is allowed to go to the next cell via the busbar by pressing the short-circuit piece and the busbar riser together [65]. When the gap between the short-circuit piece and the busbar riser is directly opened or closed under high amperage, a high-energy DC arc is formed [65]. The current switch bypass yields energy savings, emission reductions and production increases [65]. 

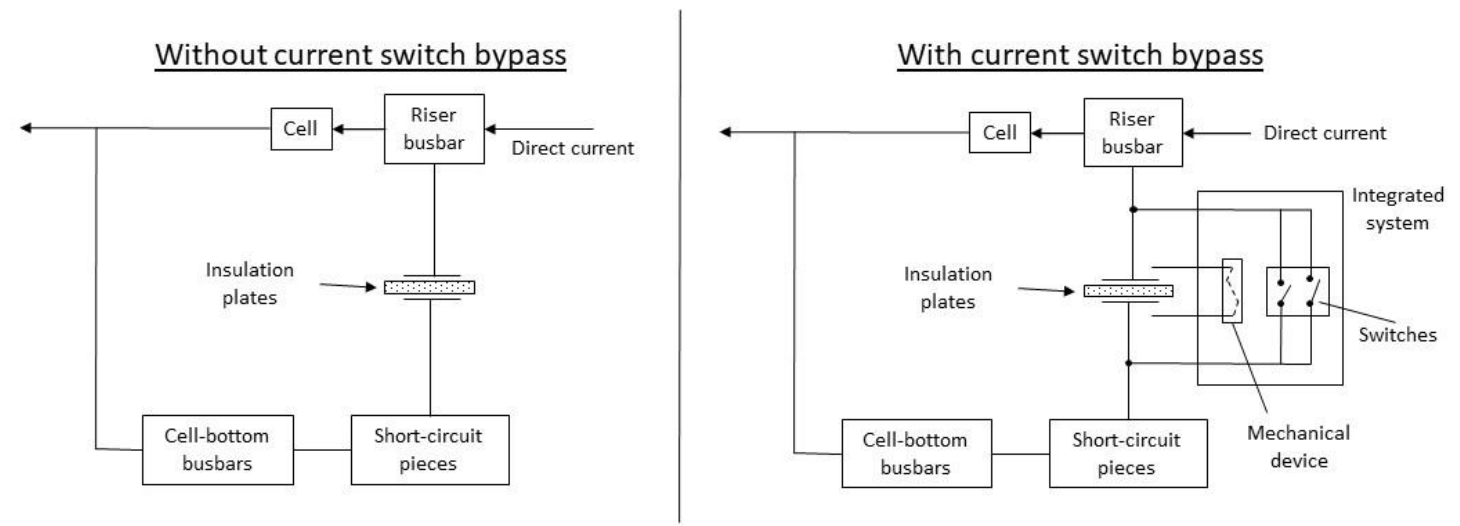

Figure 9 Schematic drawing of an electrolysis cell with and without a current switch bypass. The current switch is first closed, followed by opening or closing of the short circuit piece and finally the current switch is opened [65]. Based on [65].

\subsubsection{Improved electrical contact}

Electrical contact resistances occur in all electrical contact interfaces present in an electrolysis plant, for example busbar connections, collector bars to the busbars, risers on the electrolysis cell, breakers, rectifiers, shunts and transformers [66]. A metallic foam has been developed to improve the electrical contact between two connected surfaces [66]. The purpose is to create as many electrical connections between the two surfaces as possible and to create a gas- and liquid-tight interface [66]. More connections between the surfaces are created with increasing temperature, which further reduces the contact voltage [66]. A greater than $80 \%$ reduction in electrical resistance can be achieved by using the foam, with energy savings as a result [66]. Other benefits are improvements to the stability, reliability and lifetime of the electrical contact [66].

\subsection{Recycling}

\subsubsection{Selecting appropriate melting furnaces and feed material}

Different scrap types have their own particular challenges in the melting process [3]. The input scrap material type and its size, oxide content and degree of contamination are major factors influencing the selection of the most suitable melting furnace type to use [3].

In addition to increased energy efficiency, there is a possibility for increased recovery yield [3]. Depending on the melting technology used, the energy demand for melting and casting secondary aluminium can vary considerably [8]. Rotary furnaces with oxy-fuel burners can operate at 0.16 $\mathrm{kWh} / \mathrm{kg} \mathrm{Al}$, while inefficient reverberatory furnaces may require $1.17 \mathrm{kWh} / \mathrm{kg} \mathrm{Al} \mathrm{[8].}$

\subsubsection{Tilting rotary furnace}

Both mixing to remove impurities and adequate cover of the melt with less salt are accomplished with a tilting rotary furnace [3]. The salt usage is 3.6-18 times lower in a tilting rotary furnace compared to a rotary drum, since a smaller surface needs to be covered by salt through an adequate tilting of the furnace [3]. The tilting rotary furnaces cannot be retrofitted to existing and old furnaces [3]. Nor can they be applied for all feedstocks, since the furnace is not large enough to fit large items, and very small particles will be oxidised [3].

The energy usage and emissions from processes associated with waste treatment are reduced, because the amount of waste needing treatment is reduced [3]. There are also aluminium recovery and yield improvements as well as a widening of the range of raw materials which can be used [3]. 
The technology is economically beneficial, due to cost savings associated with the reduced purchase and treatment of salt [3].

\subsubsection{Melting cleaned scrap}

Melting cleaned scrap, i.e. scrap free from contaminants, can reduce energy use and skimmings/dross generation [3]. In some cases, the cleaning can also result in higher melting rates and reduced emissions [3]. The cleaning may include, for example, de-oiling and de-coating [3], but the cleaning processes used depend on the scrap type.

\subsubsection{Internal burner system}

The flue gas from the furnace may contain various organic compounds, depending on the scrap type and especially its organic contaminants [3]. The organic compounds are required to be further combusted due to environmental regulations, which can be done either with afterburners or with internal burner systems [3]. The internal burner system can be more favourable, since it reduces the energy usage in the furnace, while the afterburner increases the energy usage [3].

\subsubsection{Proper sealing of furnace door}

A proper sealing of the furnace door is important, since it will help to maintain a positive pressure inside the furnace [3]. A very small area for heat transfer to the outside is achieved through a high degree of embedding of the frame into the refractory material [3].

\subsubsection{Targeted fume collection}

Fume sources can change over the charging, melting and tapping cycles, and the collection fan capacity can be directed to those fume sources which change [3]. Automatically controlled dampers, which are linked to the furnace control, can be used to achieve the fume collection targeting [3]. To ensure minimum gas flow when the door is open, there is an automatic control on the burner rate during the charging [3]. With targeted ventilation instead of forced main ventilation in the production hall, energy is saved.

\subsubsection{Reverberatory furnace with side well, charge well and metal pumping/stirring}

A reverberatory furnace can be combined with a side well, a charge well and a pumping/stirring system [3], as shown in Figure 10. Heat is transferred from the main hearth to the charge well using pumping/stirring [3]. Reduction in oxidation losses as well as the possibility for fine aluminium particles to be dissolved in the circulating molten metal are achieved with the use of a side well [3]. In combination with stirring systems, the use of a charge preheating chamber is highly effective [3]. During the charge preheating, the organic contents from the scrap are pyrolysed to form hydrocarbons, which are burned off and provide energy for melting [3]. 


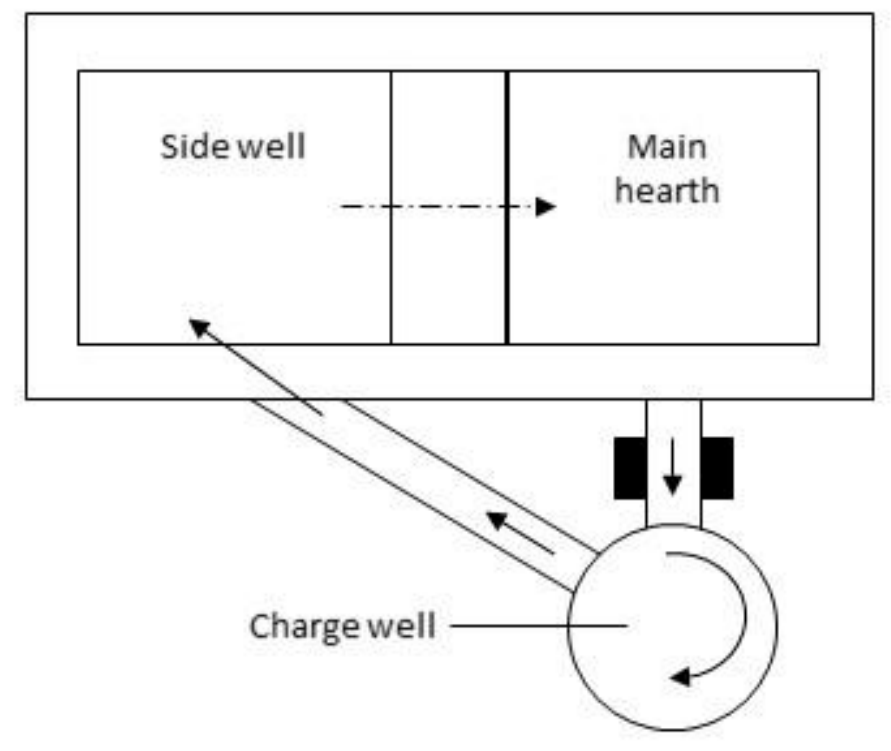

Figure 10 A reverberatory furnace with a side well, a charge well and metal pumping/stirring. Based on [3].

A reverberatory furnace with the equipment described above can use a greater range of raw materials compared to a simple reverberatory furnace [3]. The capture of furnace gases is also improved [3]. The furnace efficiency is improved by using a stirring system [3]. There is a waste amount reduction, which leads to an energy use reduction associated with the treatment of the waste as well as to a furnace emissions reduction [3]. Additionally, there are metal yield and metal quality improvements as well as energy cost and salt slag usage reductions [3].

\subsubsection{Recovery of components in skimmings, dross and salt slag}

Metallic aluminium in skimmings, dross and salt slag can be recycled back to the aluminium industry for further treatment to finished products $[13,67]$. The salts in the black dross and the salt slag can be recycled back to the secondary aluminium industry or be used in other applications, e.g. tanning and cleaning of roads $[13,67]$. Some residues containing alumina can be used in other industries, e.g. the metallurgical industry, cement industry, ceramics industry, chemical industry or agriculture $[13,67]$.

The recycling and utilisation of the different components in skimmings, dross and salt slag lead to considerable energy and economic savings, due to the replacement of primary raw materials and reduced disposal costs $[13,68]$. Environmental benefits are also achieved due to the reduced waste disposal $[13,68]$.

\subsubsection{Recycling through hot extrusion}

The remelting of scrap is traditionally used in aluminium recovery and is particularly effective for large scrap elements, since metal oxidation becomes less of a problem [69]. For small metal scraps, such as chips and filings, with a high area to volume ratio, the oxidation results in high metal losses during remelting [69].

Recycling through hot extrusion is based on the compaction of (small) aluminium scrap into billets followed by conventional hot extrusion [69-72]. To ensure proper bonding between the scrap pieces, contact between pure aluminium surfaces must be achieved through the breaking of the oxide 
layers covering the scrap pieces $[69,71]$. This is accomplished by affecting the scrap with plastic deformation and compressive stresses during the extrusion process [69]. Plastic strain can be created by pressing the chips through a special die with channels intersected at an angle after the actual extrusion [73], as shown in Figure 11. One example is the extrusion process called Cyclic Extrusion Compression, which operates at $500^{\circ} \mathrm{C}$ with five passes through the die [71]. This process has been shown to provide enough plastic deformation to consolidate the scrap particles [71]. Another issue which must be dealt with is contaminants, which require additional processes [70-72]. The scrap should also be separated into its respective alloy families [72].

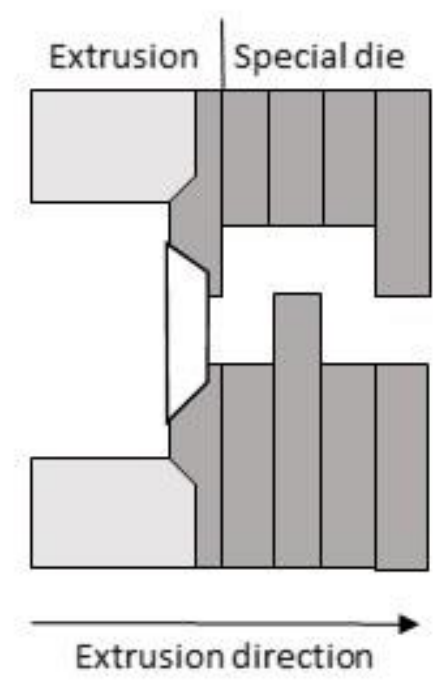

Figure 11 Schematic drawing of the special die used for creating plastic strain. Based on [73].

Compared to traditional remelting of scrap, recovery through hot extrusion has a lower energy usage as well as a higher recovery efficiency [70-72]. This means that both the production costs and solid waste generation are reduced [70]. Good material properties are also achieved [69, 70]. A nearly $90 \%$ energy saving compared to conventional recycling has been reported [74].

\subsection{Casting}

\subsubsection{Supply molten aluminium for direct moulding}

When supplying aluminium semi-products to the casting site, a remelt is needed to allow for the moulding. There is an energy usage, metal loss and pollutant emission associated with this remelt [3]. The aluminium can instead be supplied in molten form for direct moulding [3] with the use of special ladles transported by truck [75]. For this measure to be favourable, the transportation should not be longer than four to five hours [3] or 200-250 km [75]. There is an energy saving at the caster's site, since the aluminium does not need to be remelted [75]. Both the aluminium refiner and the caster can gain a storage cost saving [66]. There are also several environmental benefits $[3,75]$.

There is a reduction of the energy use of around $1 \mathrm{MWh}$ per tonne of aluminium associated with this procedure [3]. There is also a reduction in raw material usage [3]. Additionally, for the remelting furnace, there is a reduction of up to $300 \mathrm{~kg} \mathrm{CO}_{2}$ per tonne of aluminium [3]. Supplying the aluminium in molten form has an economic benefit of around 80 euro per tonne of aluminium [3]. A 
cost saving of $3-5 \%$ on the aluminium selling price for a transportation distance of $100 \mathrm{~km}$ can be achieved [75]. The cost saving depends partly on the amount of aluminium transported per day [75].

\subsubsection{Arranging orders}

When the alloy material types of the previous and the next costumer order are not similar, the material from the furnace has to be removed, stored and sent for remelting [76]. This results in scrap metal generation and additional energy and material use [76]. A reduction of $20 \%$ in scrap metal can be achieved by using computerised methods for rearranging the costumers' orders [76]. This will have an impact on the energy and raw material use [76].

\subsubsection{Electromagnetic casting}

Gulišija et al. [77] studied ingot casting with a magnetic field applied to the process. With the right frequency of the magnetic field, increased mechanical properties and better quality ingots can be achieved [77]. An energy saving can be achieved, since the increased mechanical properties result in the elimination of surface machine processing and a shortening or elimination of the homogenisation step [77].

\subsubsection{Improved practices for molten metal transfer}

Metal temperature losses between furnace tapping and mould pouring can be prevented with good practice measures such as:

- Using distribution and pouring ladles with heat-retaining covers and a volume which corresponds to the aluminium needed for filling the moulds [4].

- Using clean ladles, preheated to bright red heat [4].

- Keeping covers on empty ladles [4].

- When not in use, putting ladles upside down [4].

- Minimising the metal transfer between ladles [4].

- Conveying the metal as swiftly as possible but still within safety requirements [4].

\subsection{Anodising - new sealing methods}

Sealing methods using lower temperatures have been developed [5]. There are sealing processes operating at around $60^{\circ} \mathrm{C}[5]$. These use nickel salts rather than hydrothermal conversion of the aluminium to close the pores [5]. Processes operating at $25-35^{\circ} \mathrm{C}$ are also available and include the advantages of shorter processing time and lower energy usage [5].

\subsection{Extrusion - isothermal extrusion}

The extrudate's temperature when leaving the die is the most important factor influencing the extrudate's quality, and thus it needs to be kept constant to achieve uniform quality [78]. However, a uniformly heated billet usually experiences an increase in temperature before reaching the entrance of the die, as a result of external and internal friction as well as severe shearing deformation [78]. This yields an increase in the extruded material temperature at the die exit [78].

An undesirable grain structure along the cross section and the length of the extrudate is created, due to the variation in temperature and deformation across the cross section [79]. Depending on the application, the undesired area is in many cases machined off and discarded [79]. Isothermal extrusion is the method used to achieve a constant temperature throughout the entire extrudate [78]. Isothermal extrusion yields significant benefits for direct extrusion when, for example, it comes 
to dimensional stability, surface quality, mechanical properties and productivity [79]. The isothermal extrusion can thus reduce the material waste and the metal going to remelt, with energy savings as a result.

\subsection{Rolling - combined casting and rolling}

Casting and rolling can be combined into one process step for continuous production of aluminium strips directly from molten aluminium $[7,80]$, e.g. through the technology of twin-roll casting (shown in Figure 12) [80]. Both reduced energy need and increased productivity can be achieved [7]. The energy need for preheating, multiple passes through rolling mills, scalping and end and side trim as well as homogenisation can be saved [7]. Intermediate process steps, such as preheating and hot rolling, can be omitted, resulting in a significantly shorter process chain compared to the conventional production route [80]. In turn, this results in reduced energy use per ton of aluminium and reduced investment costs [80]. Reducing the transversal thermal variations in the process can help to further reduce the energy use as well as increase the productivity [80]. A larger than $25 \%$ energy saving compared to conventional ingot rolling has been demonstrated [7].

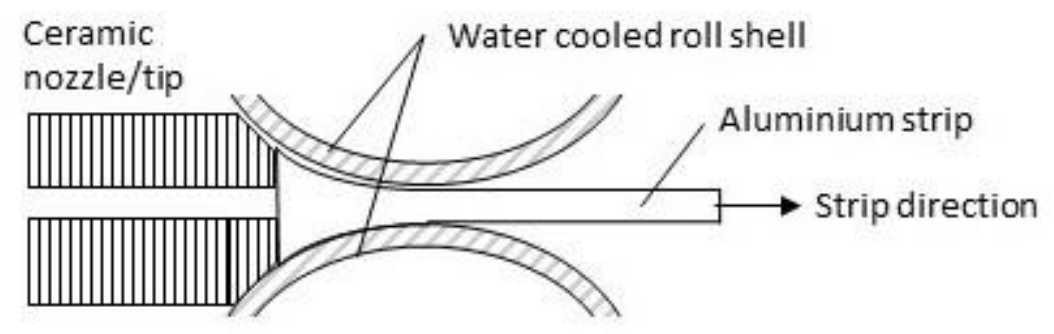

Figure 12 Schematic drawing of twin-roll casting. Molten aluminium is supplied through the ceramic nozzle/tip [80]. Based on [80].

\subsection{Heat treatment}

\subsubsection{Microwave heat treatment}

Conventional heat treatment employs furnaces, and the heat is transferred to the metal from its own surface [14]. In microwave heat treatment, heat is generated within the material as the molecules interact with the electromagnetic field [14]. Product uniformity, machining properties and mechanical properties are comparable or enhanced in microwave heat treatment compared to conventional heat treatment [14]. Microwave heat treatment also reduces power/energy demand and processing time compared to conventional heat treatment [14].

\subsubsection{Heating aging treatment or cooling aging treatment}

Both Heating Aging Treatment (HAT) and Cooling Aging Treatment (CAT) are non-isothermal aging treatment processes and can be considered to consist of infinitely many stages of isothermal aging treatment $[81,82]$. Compared to the single-stage T6 aging treatment, HAT and CAT can provide a lower energy need and improved production efficiency through lower processing time as well as improved mechanical properties and corrosion resistance [81, 82].

\subsubsection{Heat treatment based on casting method}

For components cast by processes with high cooling rates, for example high pressure die casting and low pressure permanent mould, the heat treatment standards are often not well optimised [83]. The long and expensive T6 and T7 treatments should not be needed, due to the inherently finer as-cast 
structures [83]. Modified versions of T4, T5 and T6 treatments can be used instead [83]. These can provide reductions in energy use and overall costs as well as lowering the processing time by 68$92 \%$ [83]. Additionally, the metallurgical characteristics of the component are maintained or even improved [83].

\subsection{Emerging/novel technologies}

\subsubsection{General measures - HTS induction furnace}

Conventional induction furnaces for preheating have an efficiency of $50-60 \%[84,85]$. The novel induction furnace with high-temperature superconducting (HTS) magnets has been proposed to achieve a higher energy efficiency [84, 85]. An alternating current version of the HTS induction furnace can achieve an estimated efficiency of $68.2 \%$ [85]. A direct current version can achieve an efficiency above $90 \%$ [84]. A feasibility study has shown promising results for a direct current HTS induction furnace with a power of $300 \mathrm{~kW}$ or above [84]. However, the investment rate of return showed that it is not worth investing in a capacity smaller than $60 \mathrm{~kW}$ at the moment [84].

\subsubsection{Electrolysis}

\subsubsection{Lower temperature electrolytes}

Sodium cryolite used in the conventional electrolytic cell is a reason for the high energy use of the electrolysis cell [86]. This is due to the high melting temperature of the sodium cryolite $\left(1,01{ }^{\circ} \mathrm{C}\right)$ [86]. The operating temperature for electrolysis is reduced by the addition of $\mathrm{AlF}_{3}, \mathrm{Al}_{2} \mathrm{O}_{3}, \mathrm{CaF}_{2}, \mathrm{MgF}_{2}$ and LiF [86] to between $900{ }^{\circ} \mathrm{C}$ [87] and $970{ }^{\circ} \mathrm{C}$ [86]. The operating temperature has been a barrier to further reductions of the energy demand of electrolysis [87]. Heat losses from the hightemperature molten cryolite-based salts account for more than $50 \%$ of the electricity demand, which implies the need for the development of novel electrolytes [87].

Low-melting electrolytes can effectively improve current efficiency, reduce energy use and extend the lifespan of the electrolysis cell compared to the present electrolysis process [86]. Finding a solvent for alumina with a lower liquidus temperature ${ }^{2}$ and suitable physiochemical properties is one of the key problems [86]. Potassium cryolite $\left(\mathrm{K}_{3} \mathrm{AlF}_{6}\right)$ is one of the few compounds which can fulfil these requirements as well as providing a much wider range of low-temperature liquid composition than electrolytes based on sodium cryolite [86]. Potassium cryolite has shown a potential for lower electrolyte temperatures [88] and energy savings in aluminium production [89]. However, the $\mathrm{K}_{3} \mathrm{AlF}_{6}$-based electrolytes have shown a low electrical conductivity, which might be compensated for by adding lithium fluoride $[86,89]$ and sodium fluoride [86]. Low-melting electrolytes might present a higher voltage drop, which can be compensated for by reduced ACD or lower current density [86]. If successful, the $\mathrm{K}_{3} \mathrm{AlF}_{6}$-based electrolytes can lower the electrolysis temperature to $700-750^{\circ} \mathrm{C}$ and thus provide energy savings [90]. A combination of sodium and potassium electrolytes can also be used $[88,91]$. However, the electrolysis temperature used for this combination may be around $800-850^{\circ} \mathrm{C}$ [91]. Additionally, the alumina solubility is lower for the potassium and sodium cryolite combination than for only potassium cryolite, which results in lower electrolysis efficiency [88].

A new class of room-temperature molten salts is the ionic liquids, which give excellent physicochemical properties [87]. Using ionic liquids in the electrolysis process will significantly lower

\footnotetext{
${ }^{2}$ The temperature above which the solvent is completely liquidised
} 
the operating temperature to $<150{ }^{\circ} \mathrm{C}$ and the energy demand to $<11 \mathrm{kWh} / \mathrm{kg}$ [87]. Additionally, it is expected that the current efficiency and the aluminium quality will be improved [87]. However, a more stable electrolyte based on ionic liquids and allowing for higher current densities needs to be developed [56]. This is important for achieving similar production levels as today's facilities [56] without building facilities which are much larger than today's facilities.

\subsubsection{Wettable cathodes}

Better energy efficiency for electrolysis is achieved through the development of new cathode materials or coatings for existing cathode materials [3]. Wettable cathodes ${ }^{3}$ are still at the development stage [3] and have been tested in research cells [3, 92] and on an industrial scale [92].

When using conventional cathodes, a significant metal pad is required on the cathode's surface to provide a certain protection [93] against the corrosive electrolyte [94]. However, movements and standing waves in the aluminium as well as aluminium/electrolyte interference are created due to electromagnetic forces $[93,95,96]$. This results in a large ACD to avoid shortening between the anodes and the metal $[93,95,96]$. Wettable cathodes allow the molten metal to wet the cathode, and a high aluminium pad is not needed [93, 96, 97]. A thin, stable aluminium layer can be formed and the ACD can be reduced $[93,96,97]$ without an adverse effect on the current efficiency, since the enormous magnetic field disturbance is reduced [93]. A reduction in the energy use is achieved by reduced cathodic voltage [90] and by reduced ACD $[93,95-97]$ through reduced electrolyte voltage $[93,95,96]$.

Table 3 shows some energy saving potentials for wettable cathodes reported in the literature.

Table 3 Energy saving potentials for wettable cathodes.

\begin{tabular}{|c|c|c|c|}
\hline Based on & Energy saving potential & Comment & Reference \\
\hline $\begin{array}{l}\text { Replacing conventional } \\
\text { cathodes in a cell using } \\
14 \mathrm{kWh} / \mathrm{kg} \mathrm{Al}\end{array}$ & $2.6-3.1 \mathrm{kWh} / \mathrm{kg} \mathrm{Al}$ & & [92] \\
\hline $\begin{array}{l}\text { Replacing conventional } \\
\text { cathodes in a cell using } \\
13.5 \mathrm{kWh} / \mathrm{kg} \text { Al and } \\
350 \mathrm{kA}\end{array}$ & $1.5 \mathrm{kWh} / \mathrm{kg} \mathrm{Al}$ & $\begin{array}{l}\text { Taking into account an increase } \\
\text { of the current to } 375 \mathrm{kA} \text { that is } \\
\text { needed for achieving a practical } \\
\text { heat balance in the cell }\end{array}$ & [97] \\
\hline $\begin{array}{l}\text { Replacing conventional } \\
\text { cathodes in a cell using } \\
14.3 \mathrm{kWh} / \mathrm{kg} \mathrm{Al}\end{array}$ & $2.3 \mathrm{kWh} / \mathrm{kg} \mathrm{Al}$ & & [101] \\
\hline Industrial scale test & $0.4 \mathrm{kWh} / \mathrm{kg} \mathrm{Al}$ & $\begin{array}{l}\text { A reduction of the } \mathrm{Na}_{2} \mathrm{CO}_{3}{ }^{1} \text { use } \\
\text { of } 1.7 \text { tons during cell start-up, } \\
\text { was also achieved }\end{array}$ & [95] \\
\hline
\end{tabular}

${ }^{1} \mathrm{Na}_{2} \mathrm{CO}_{3}$ is added to compensate for sodium losses and to maintain optimal bath chemistry [98].

\subsubsection{Inert anodes}

Inert, or non-consumable, anodes for aluminium electrolysis can give potential energy [99, 100], environmental and cost benefits if the technology is successful [99-101], including the elimination of the process-related GHG emissions [99-102]. However, inert anodes are still at the pilot plant stage [3]. Major challenges are the temperatures [3], the corrosive electrolyte [3, 100, 102] and finding

\footnotetext{
${ }^{3}$ Also known as drained cathodes or dimensionally stable cathodes
} 
conducting or semiconducting materials which do not dissolve in the electrolyte $[8,100]$. A material with long-term stability in conventional electrolytic cells had not been found as of 2014 [8]. However, the main material groups for inert anodes so far are cermets, metals $[100,101]$ and ceramics [101].

The lifetime of the inert anodes is expected to be much longer compared to carbon anodes, which would lead to fewer anode changes [99]. An inert anode with the same lifetime as the cell would be optimal, since no anode changes would be necessary once the cell was started [101].

The oxygen gas, which evolves when using inert anodes, can be seen as a value-added by-product [100], which can be sold, thus improving the energy and cost balance of the process.

The decomposition voltage of alumina when using inert anodes is about $1 \mathrm{~V}$ higher than when using carbon anodes $[8,100]$. Cell design changes which reduce the ACD may possibly offset this increase in decomposition voltage [8]. In a case when inert anodes are used in combination with conventional cathodes, the ACD reduction may not be sufficiently large to provide for energy benefits [99]. For the combination of inert anodes and wettable cathodes, energy saving potentials exist [99]. The elimination of carbon anode production will also yield energy savings [99, 100]. Improved thermal efficiency should also be present when using inert anodes, due to better insulation [99].

Table 4 shows some energy saving potentials for inert anodes reported in the literature. Note that the direct retrofit of inert anodes has a negative potential saving, or is approximately unchanged at best, implying that the energy demand increases for the electrolysis. However, when taking the energy demand for producing the anodes into account, there is a potential energy saving.

Table 4 Energy saving potentials for inert anodes.

\begin{tabular}{|l|l|l|l|}
\hline Based on & Energy saving potential & Comment & Reference \\
\hline $\begin{array}{l}\text { Electrolysis with direct } \\
\text { retrofit in a cell using } \\
15 \mathrm{kWh} / \mathrm{kg} \text { Al }\end{array}$ & $-2.85-0 \mathrm{kWh} / \mathrm{kg} \mathrm{Al}$ & $\begin{array}{l}\text { If new or significantly improved } \\
\text { cell designs can be developed, } \\
\text { the potential may possibly } \\
\text { change }\end{array}$ & {$[103]$} \\
\hline $\begin{array}{l}\text { Electrolysis + anode } \\
\text { production with direct } \\
\text { retrofit }\end{array}$ & $\begin{array}{l}1 \mathrm{kWh} / \mathrm{kg} \mathrm{Al} \text { or 7\% from } \\
\text { the } 2001 \text { level }\end{array}$ & Same as above & {$[103]$} \\
\hline $\begin{array}{l}\text { Electrolysis with inert } \\
\text { anodes and wettable } \\
\text { cathodes }\end{array}$ & $25 \%$ & This is a "best estimate" & {$[99]$} \\
\hline $\begin{array}{l}\text { Electrolysis with inert } \\
\text { anodes and wettable } \\
\text { cathodes }\end{array}$ & $\begin{array}{l}2.4 \mathrm{kWh} / \mathrm{kg} \text { Al during } \\
\text { anode production }+ \\
\text { savings during } \\
\text { electrolysis from using } \\
\text { wettable cathodes }\end{array}$ & $\begin{array}{l}14 \mathrm{kWh} / \mathrm{kg} \mathrm{Al} \mathrm{for} \mathrm{electrolysis} \\
\text { and } 2.5-3 \mathrm{kWh} / \mathrm{kg} \text { Al for anode } \\
\text { production as base case }\end{array}$ & {$[90]$} \\
\hline
\end{tabular}

\subsubsection{Gas anodes}

Gas anodes are based on the use of porous anodes, either carbon or inert anodes, together with methane being supplied through the anode to the electrolysis cell [104]. The methane is used, in addition to the anode, as a reducing agent in the production of aluminium [104]. A reduction of the anode carbon consumption by $44 \%$ can be achieved with gas anodes in the best case scenario [104]. 
However, due to unwanted side reactions, the savings potential is lower [104]. Gas anodes may also significantly reduce energy use and $\mathrm{CO}_{2}$ emission and potentially eliminate the PFC emissions [104]. Methane's low price, relative abundance and high purity make it attractive [104]. However, industrial electrolysis processes have not fully implemented the gas anode concept [104]. Major challenges include optimising anode porosity, graphite structure and gas flow as well as minimising the cracking of methane [104].

\subsubsection{Vertical electrode cells}

Vertical electrode cells (VEC) use several vertical electrodes where every second electrode is a cathode and every alternate is an anode [105], as shown in Figure 13. This new cell design is based on the use of inert anodes, wettable cathodes and low-temperature electrolytes [105].

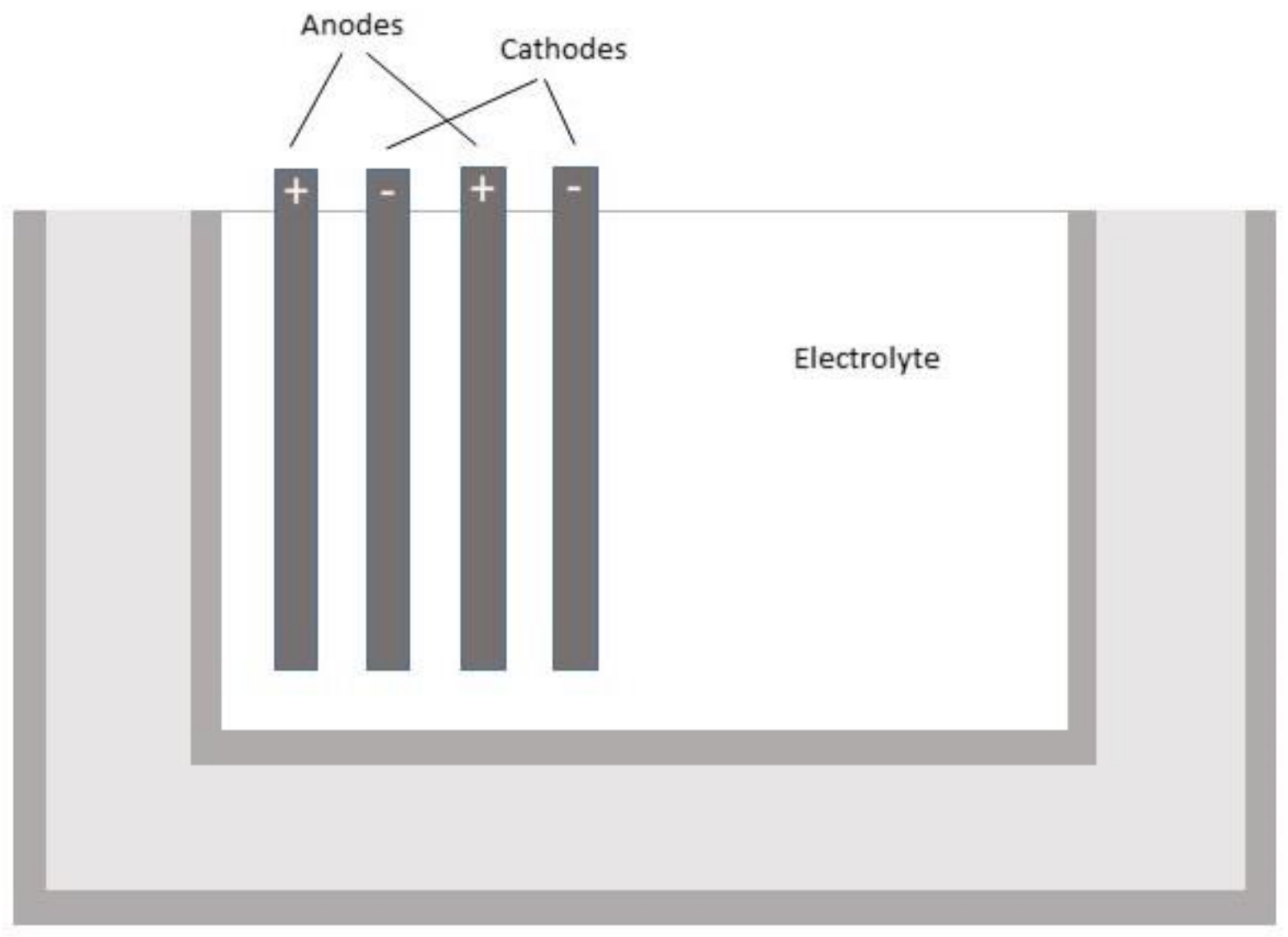

Figure 13 Schematic drawing of vertical electrode cell. Based on [137].

A reduction from the typical industry value (in 2007) of $15 \mathrm{kWh} / \mathrm{kg}$ Al for the conventional HallHéroult process to about $11 \mathrm{kWh} / \mathrm{kg}$ has been predicted for the VEC configuration [105]. This corresponds to a reduction in the order of $25-30 \%$ [105]. The PFC emissions are expected to be eliminated [105].

\subsubsection{Corrosion-resistant sidewall refractory}

To prevent corrosion attack on today's sidewall refractories, a solid ledge of cryolite needs to be formed [106] (see Figure 3). A large energy flux through the sidewall is required for the ledge to form and remain stable, which can account for up to $35 \%$ of the electricity input to the electrolysis [106]. The cryolite ledge can be eliminated by using a corrosion-resistant sidewall refractory, for example nickel ferrite spinel [106]. Increased energy efficiency is achieved, since the energy flux through the 
sidewall can be reduced [106]. Both productivity and capacity could be increased for the same cell dimension, since larger anodes may be used [106].

\subsubsection{Carbothermic reduction}

Instead of the electrochemical reduction in the Hall-Héroult process, the chemical reduction of aluminium can be performed through the carbothermic process [7]. Compared to the Hall-Héroult process, carbothermic reduction provides the potential for both lower energy usage [107-110] and increased productivity [107-109]. Despite this, the proposed processes have not been commercialised [107]. For the direct carbothermic reduction, there have been problems with extreme operating conditions, yield [107], the formation of aluminium carbide, high temperatures [108-110], energy delivery for reaching the temperatures $[108,109,111]$, aluminium volatiles [108$111]$, the formation of undesired by-products $[112,113]$ and complicated back-reaction [110]. More knowledge about the reaction mechanisms and kinetics of alumina reduction is needed to overcome these problems $[108,109]$. Further development is also needed in indirect carbothermic reductions [107]. Additionally, Xia et al. [114] reported a higher theoretical energy use for the carbochlorination route compared to the Hall-Héroult process.

In the direct carbothermic reduction, the alumina is first converted to aluminium carbide, which is then reduced by alumina to produce metallic aluminium $[7,115]$. The temperature used for the first stage can be from about $1900{ }^{\circ} \mathrm{C}$ [7] to $2030^{\circ} \mathrm{C}$ [115]. For the second stage, the temperature can be from about $2000{ }^{\circ} \mathrm{C}$ [7] to $2130^{\circ} \mathrm{C}$ [115]. This reaction chain can provide aluminium yields as high as $67 \%$ [115]. Some companies are still working on the development of the carbothermic reduction process [8], increasing the yield through either the development of specific reactors with advanced vapour management and better thermal efficiency or alternative chemical routes, such as the hightemperature route $\left(2100-2400^{\circ} \mathrm{C}\right)$ [115]. In the high-temperature route, carbide formation is avoided, with achieved aluminium yields as high as 90\% [115].

Table 5 shows some energy saving potentials for direct carbothermic reduction, as reported in the literature. 
Table 5 Energy saving potentials for direct carbothermic reduction.

\begin{tabular}{|c|c|c|c|}
\hline Based on & Energy saving potential & Comment & Reference \\
\hline $\begin{array}{l}\text { Comparison to an } \\
\text { electrolysis cell using } \\
14.4 \mathrm{kWh} / \mathrm{kg} \mathrm{Al}\end{array}$ & $5.33 \mathrm{kWh} / \mathrm{kg} \mathrm{Al}$ or $37 \%$ & $\begin{array}{l}\text { The estimate used the } \\
\text { theoretical minimum energy } \\
\text { use for direct carbothermic } \\
\text { reduction with account taken } \\
\text { of thermal losses and } \\
\text { inefficiencies in control system } \\
\text { and off-gas recovery }\end{array}$ & [7] \\
\hline Comparison of reactions & $\begin{array}{l}33 \% \text { (for onsite energy } \\
\text { and tacit energy) }\end{array}$ & & [7] \\
\hline $\begin{array}{l}\text { Comparison of reactions } \\
+ \text { anode } \\
\text { material/reaction } \\
\text { carbon }\end{array}$ & $\begin{array}{l}36 \% \text { (onsite energy) or } \\
22 \% \text { (tacit energy) }\end{array}$ & & [7] \\
\hline Comparison of reactions & At least $16 \%$ & For a process at $2,100{ }^{\circ} \mathrm{C}$ & [115] \\
\hline $\begin{array}{l}\text { Comparison to an } \\
\text { electrolysis cell using } \\
13 \mathrm{kWh} / \mathrm{kg} \mathrm{Al}\end{array}$ & $2 \mathrm{kWh} / \mathrm{kg}$ Al or $15.4 \%$ & & [101] \\
\hline $\begin{array}{l}\text { Comparison to an } \\
\text { electrolysis cell using } \\
13.8 \mathrm{kWh} / \mathrm{kg} \mathrm{Al} \text { and } \\
400 \mathrm{kA}\end{array}$ & $\begin{array}{l}7.08 \mathrm{kWh} / \mathrm{kg} \text { Al or } \\
51.3 \%\end{array}$ & & [111] \\
\hline $\begin{array}{l}\text { Comparison to an } \\
\text { electrolysis cell using } \\
13.8 \mathrm{kWh} / \mathrm{kg} \mathrm{Al} \text { and } \\
400 \mathrm{kA}\end{array}$ & $\begin{array}{l}5.405 \mathrm{kWh} / \mathrm{kg} \mathrm{Al} \text { or } \\
28.75 \%\end{array}$ & $\begin{array}{l}\text { Based on the concept of } \\
\text { process fuel equivalent }\end{array}$ & [111] \\
\hline
\end{tabular}

The specific GHG emissions are higher for the carbothermic process compared to the Hall-Héroult process when just taking the carbon consumption into account $[101,111]$. However, if the PFC emissions occurring due to the anode effect in the Hall-Héroult process are accounted for, the specific GHG emissions are lower for the carbothermic process than for the Hall-Héroult process [111]. The electricity use also has an impact on the overall GHG emissions [101, 115].

The carbothermic reduction has a much lower need for physical space and has a lower dependency on economies of scale than the Hall-Héroult process [7]. The capital costs can be reduced [7, 107110 ] by $50 \%$ or more, and the production costs can be reduced by $25 \%$ [7]. There is a greater freedom to relocate the reduction plants closer to the casting facility, which allows for additional energy, economic and environmental benefits [7].

There are three types of indirect carbothermic reduction routes, briefly described in Table 6 . In these, alumina and/or aluminium ore are first converted to intermediate aluminium compounds, which are then further reduced to extract metallic aluminium [107]. 
Table 6 The different indirect carbothermic reduction routes. Adapted from Rhamdhani et al. [107].

\begin{tabular}{|c|c|c|c|}
\hline Route & $\begin{array}{l}\text { Reaction } \\
\text { components }^{1}\end{array}$ & $\begin{array}{l}\text { Intermediate } \\
\text { compounds }\end{array}$ & Possible extraction methods ${ }^{2}$ \\
\hline Carbochlorination & $\begin{array}{l}\text { Carbon } \\
\text { Chlorine sources }\end{array}$ & $\begin{array}{l}\text { Aluminium chloride } \\
\text { compounds }\end{array}$ & $\begin{array}{l}\text { Disproportionation } \\
\text { Electrolysis } \\
\text { Distillation } \\
\text { Direct reduction with other metals }\end{array}$ \\
\hline Carbosulphidation & $\begin{array}{l}\text { Carbon } \\
\text { Sulphur sources }\end{array}$ & $\begin{array}{l}\text { Aluminium } \\
\text { sulphide } \\
\text { compounds }\end{array}$ & $\begin{array}{l}\text { Disproportionation } \\
\text { Electrolysis }\end{array}$ \\
\hline Carbonitridation & $\begin{array}{l}\text { Carbon } \\
\text { Nitrogen sources }\end{array}$ & $\begin{array}{l}\text { Aluminium nitride } \\
\text { compounds }\end{array}$ & $\begin{array}{l}\text { Disproportionation } \\
\text { Electrolysis }\end{array}$ \\
\hline
\end{tabular}

${ }^{1}$ In addition to alumina and/or aluminium ore

${ }^{2}$ Extraction of metallic aluminium from the intermediate compounds. Choosing one of the methods will suffice.

\subsubsection{Recycling - spark plasma sintering}

Spark Plasma Sintering (SPS) can be used as a recycling method for producing fully dense/voidless billets or near-net or even final-shape products directly from aluminium turnings or chips [74]. The scrap is first pre-compacted at room temperature and is then sintered below the solidus temperature at $490^{\circ} \mathrm{C}$ under $200 \mathrm{MPa}$ pressure [74]. Further research is needed to identify the optimum set of parameters for the SPS method [74]. The SPS technology can provide both energy and material savings compared to conventional remelting of scrap [74]. The material savings arise from the reduced problem of oxidation losses, which is a larger problem for smaller scrap such as turnings and chips [74]. The SPS technology has been shown to have a 90-95\% lower energy demand than conventional hot pressing (HP) sintering technology, due to reduced sintering temperature and processing time [116]. Similar or better material properties are achieved with SPS compared to HP [116]. Figure 14 shows a schematic drawing of both SPS and HP sintering. The main difference between SPS and HP sintering is the energy supply method [116], which is shown in Figure 14.

Spark plasma sintering (SPS)

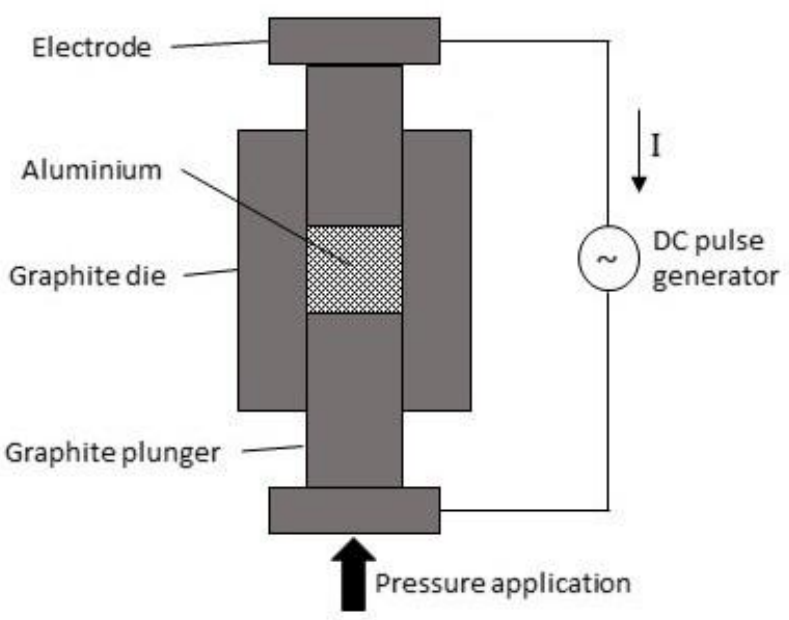

Hot pressing (HP) sintering

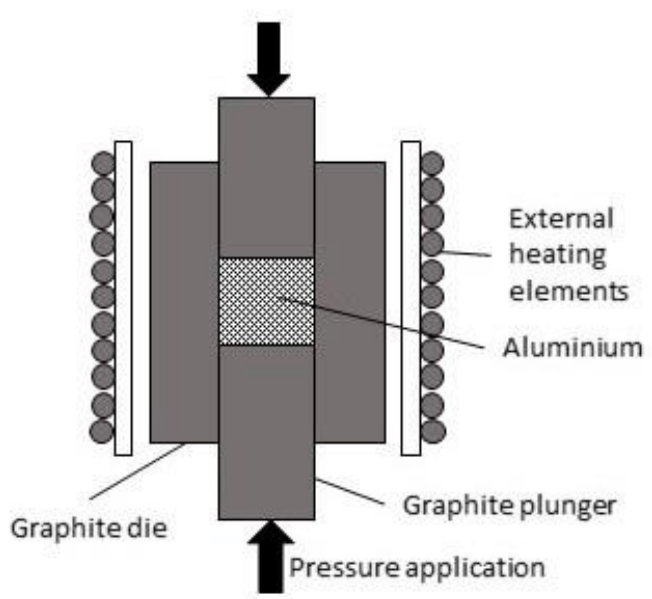

Figure 14 Schematic drawing of spark plasma sintering and hot pressing sintering. Based on [116]. 


\subsubsection{Casting - CRIMSON casting}

CRIMSON casting is a novel shape-casting method, which employs an induction furnace to melt just enough metal to fill a single mould [117-119]. When the metal has melted, the crucible is moved to an up-caster where a piston raises and pushes the metal into the mould [118]. The up-casting method is computer-controlled [117-119] to achieve optimal filling and solidification [118]. The mould can be moved to a transfer stop after cooling down and solidification, where the mould is waiting for lifting and cleaning [118].

Table 7 shows energy saving potentials for CRIMSON casting reported in the literature. These estimations are based on different assumptions.

Table 7 Energy saving potentials for CRIMSON casting.

\begin{tabular}{|l|l|l|l|}
\hline Based on & Energy saving potential & Comment & Reference \\
\hline $\begin{array}{l}\text { Comparison to } \\
\text { investment casting }\end{array}$ & $\begin{array}{l}64 \% \text { when producing } \\
\text { one filter housing }\end{array}$ & $\begin{array}{l}42-70 \% \text { improvement in } \\
\text { casting yield }\end{array}$ & {$[117]$} \\
\hline $\begin{array}{l}\text { Comparison to } \\
\text { investment casting }\end{array}$ & $1.3 \mathrm{kWh} / \mathrm{kg} \mathrm{Al}$ & & {$[119]$} \\
\hline $\begin{array}{l}\text { Comparison to sand } \\
\text { casting }\end{array}$ & $7.19 \mathrm{kWh} / \mathrm{kg} \mathrm{Al}$ & & {$[118]$} \\
\hline
\end{tabular}

\subsubsection{Rolling - Al-Cu-Mn-Zr sheet alloys}

There is a possibility of obtaining cold rolled sheets directly from cast billets without homogenisation in furnaces by using alloys of the Al-Cu-Mn-Zr system [120]. High ductility and production of thin defect-free sheets is achieved with the near single phase structure provided in the as-cast state [120]. This type of sheet alloy can be produced using conventional facilities for melting, casting, rolling and so on [120]. However, these alloys are still at the research stage [120].

Compared to commercial alloys of the $2 x x x$ series, economic, operational and environmental benefits could be accompanied by the use of the above given sheet alloys [120,121]. By elimination of the homogenisation, solution treatment and quenching, a more energy efficient production line with lower electricity usage is achieved [120,121]. Due to the elimination of the quenching step, the product rejection is decreased $[120,121]$. This might result in a reduction of the amount of process scrap.

\section{Discussion}

\subsection{Number of measures}

In this review, the largest number of energy efficiency measures has been found for the electrolysis. One reason for this may be that electrolysis is the most energy-intensive process in aluminium production and that it has therefore gained the most focus in RD\&D [122]. For electrolysis, there is also a higher number of emerging/novel measures compared to the other production processes. This can be explained by the fact that the high energy intensity implies a greater need for novel technologies to reduce the energy demand. General energy efficiency measures and recycling ended up in a shared second place in the number of measures found. For the general measures, this might be explained partially by their relatively wide applicability. Improved energy efficiency in recycling is important with respect to several aspects such as environmental and economic concerns and 
strengthened competitiveness in a future with an increased demand for aluminium and where the increased demand advantageously could be met through recycling rather than through primary production. For the other production processes, the number of measures found was generally quite low. One reason might be that to some extent, these processes do not demand as much energy compared, for example, to electrolysis, and that therefore, they do not gain as much interest in research.

\subsection{Comparison between energy efficiency measures}

This part will provide summaries of the energy saving potentials that were found in the literature and will discuss possible combinations of the presented energy efficiency measures. For the emerging/novel technologies, the discussion assumes that they will become commercially available in the future. In this discussion, a possible combination means that there is no technical obstacle to combining the measures, that is, the measures can be implemented either separately or together. However, the total energy savings potential for the combination may be lower than the sum of the potentials for the individual measures.

\subsubsection{General measures}

Table 8 shows which of the general measures can possibly be combined. The reduction of process scrap relates to all processes where scrap occurs, while the other measures relate to furnaces or heated processes. Since the reduction of process scrap generally does not hinder energy efficiency improvements in furnaces and heated processes, measures to reduce process scrap can be implemented without affecting the potential of other general measures. Some of the other measures can possibly be combined, since they affect different parts of the furnace or affect the same type of furnace. Oxy-fuel combustion and a non-stationary flame burner cannot be implemented in an HTS induction furnace, since they are based on a furnace technology utilising burners. It is uncertain whether an immersed furnace heater and a non-stationary flame burner can be combined, since it is unknown whether the immersed heater can be moved. 
Table 8 Possible combination of general measures. $X$ means that a combination is possible. - means that the measures are mutually exclusive. ? means that a possible combination unknown.

\begin{tabular}{|c|c|c|c|c|c|c|c|c|c|c|}
\hline & 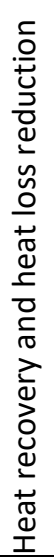 & 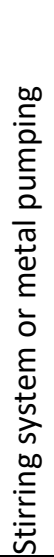 & 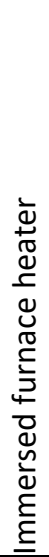 & 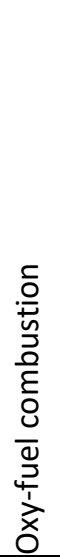 & 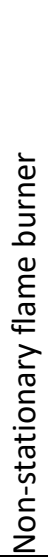 & 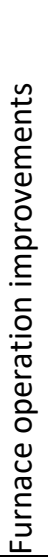 & 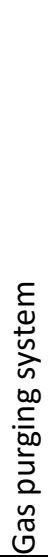 & 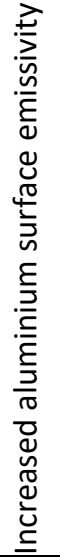 & 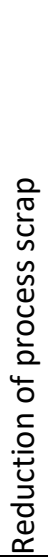 & 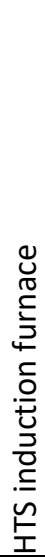 \\
\hline Heat recovery and heat loss reduction & & $\mathrm{X}$ & $\mathrm{X}$ & $\mathrm{X}$ & $\mathrm{X}$ & $\mathrm{X}$ & $\mathrm{X}$ & $X$ & $X$ & $\mathrm{x}$ \\
\hline Stirring system or metal pumping & $\mathrm{X}$ & & $x$ & $\mathrm{X}$ & $\mathrm{X}$ & $\mathrm{X}$ & $x$ & $\mathrm{X}$ & $\mathrm{X}$ & $\mathrm{X}$ \\
\hline Immersed furnace heater & $\mathrm{X}$ & $\mathrm{X}$ & & $\mathrm{X}$ & $?$ & $\mathrm{x}$ & $\mathrm{X}$ & $\mathrm{X}$ & $\mathrm{X}$ & $\mathrm{X}$ \\
\hline Oxy-fuel combustion & $\mathrm{X}$ & $\mathrm{X}$ & $\mathrm{X}$ & & $\mathrm{X}$ & $\mathrm{x}$ & $\mathrm{X}$ & $\mathrm{X}$ & $\mathrm{X}$ & - \\
\hline Non-stationary flame burner & $\mathrm{X}$ & $\mathrm{X}$ & $?$ & $\mathrm{x}$ & & $\mathrm{x}$ & $\mathrm{X}$ & $\mathrm{X}$ & $\mathrm{X}$ & - \\
\hline Furnace operation improvements & $\mathrm{X}$ & $\mathrm{X}$ & $\mathrm{X}$ & $\mathrm{X}$ & $X$ & & $\mathrm{x}$ & $\mathrm{X}$ & $x$ & $\mathrm{X}$ \\
\hline Gas purging system & $\mathrm{X}$ & $\mathrm{X}$ & $\mathrm{X}$ & $\mathrm{x}$ & $\mathrm{X}$ & $x$ & & $\mathrm{X}$ & $\mathrm{x}$ & $\mathrm{X}$ \\
\hline Increased aluminium surface emissivity & $\mathrm{X}$ & $\mathrm{X}$ & $\mathrm{X}$ & $\mathrm{X}$ & $\mathrm{X}$ & $\mathrm{x}$ & $\mathrm{X}$ & & $\mathrm{X}$ & $\mathrm{X}$ \\
\hline Reduction of process scrap & $\mathrm{X}$ & $\mathrm{X}$ & $\mathrm{X}$ & $\mathrm{X}$ & $X$ & $\mathrm{X}$ & $\mathrm{X}$ & $\mathrm{X}$ & & $\mathrm{X}$ \\
\hline HTS induction furnace & $\mathrm{X}$ & $X$ & $\mathrm{x}$ & - & - & $x$ & $x$ & $X$ & $X$ & \\
\hline
\end{tabular}

Table 9 shows a compilation of energy saving potentials for general measures. Note that not all submeasures are presented for heat recovery and heat loss reduction and furnace improvements. As seen in Table 8, many of the measures can be combined, which implies that the highest savings potential can be achieved by combining the measures. However, the sub-measures of regenerative burners, heat exchanger on exhaust gases, preheating of combustion air with heat from exhaust gases and preheat hearth all use heat from the furnace exhaust gases. This means that these submeasures may not be possible to combine, since the exhaust gas temperature may be too low when leaving the heat recovery utilising one of the sub-measures. The sub-measure with the highest savings potential should be used. However, this may vary from case to case, and not all submeasures may be applicable in all cases, so an investigation for every case is needed. 
Table 9 Compilation of the energy saving potentials for the general measures. - means that no energy saving potential was found.

\begin{tabular}{|c|l|l|}
\hline Measure & Energy saving potential & References \\
\hline Heat recovery and heat loss reduction & & \\
\hline$-\quad$ Regenerative burners & Up to $40 \%$ & {$[21,24]$} \\
\hline$-\quad$ Heat exchanger on exhaust gas, large furnace & $23 \%$ & {$[21]$} \\
\hline$-\quad$ Better insulation material & $2-5 \%$ & {$[6]$} \\
\hline$\quad$ greheat combustion air with heat from exhaust & $10-30 \%$ & {$[6]$} \\
\hline$-\quad$ Preheat hearth & & \\
\hline Metal pumping system, reverberatory furnace & $15 \%$ & {$[21]$} \\
\hline Immersed furnace heater & $10-20 \%$ & {$[27]$} \\
\hline Oxy-fuel combustion & Up to $66.7 \%$ & {$[29]$} \\
\hline Non-stationary flame burner & $50-60 \%$ & {$[4,30]$} \\
\hline Furnace operation improvements & - & \\
\hline$-\quad$ The use of air-fuel control system & & \\
\hline$-\quad$ The use of furnace pressure system & $5-15 \%$ & {$[6]$} \\
\hline$-\quad$ Adjustment of burners for efficient operation & $5-10 \%$ & {$[6]$} \\
\hline$-\quad$ Improved control systems & $5-10 \%$ & {$[6]$} \\
\hline Gas purging system & $5-10 \%$ & {$[6]$} \\
\hline Increased aluminium surface emissivity & $15 \%$ & {$[34]$} \\
\hline Reduction of process scrap & $18 \%$ or $0.3 \mathrm{kWh} / \mathrm{kg} \mathrm{Al}$ & {$[35]$} \\
\hline HTS induction furnace & $6 \%$ & {$[2]$} \\
\hline
\end{tabular}

It is always good practice to minimise the amount of process scrap which occurs in the production. However, there is an upper limit to how much the process scrap can be reduced, due to, for example, technical reasons.

Oxy-fuel combustion will provide an energy saving in the furnaces in the aluminium industry. However, there is an energy need in the production of the oxygen, which from a system perspective will lower the energy saving.

\subsubsection{Electrolysis}

Table 10 shows which of the measures for electrolysis can possibly be combined. One reason that so many measures can be combined is that in many cases, they affect different parts of the cell or have been described as actually working together. However, cells with vertical electrodes may eliminate the need for slotted or perforated anodes, since the anode gas can dissipate between the electrodes. Both novel structure cathodes and wettable cathodes achieve a reduction in the ACD by weakening the fluctuations in the molten metal layer. Since they achieve the same positive effect, it may be that using only one will suffice. Novel structure cathodes may be easier to implement in the near term, while wettable cathodes may be a longer-term solution. Graphitised cathodes and wettable cathodes can be combined, since wettable cathodes can imply coating for existing cathode materials. Carbothermic reduction is supposed to replace the Hall-Héroult process and has other characteristics than the Hall-Héroult process. Carbothermic reduction thus excludes all measures designed for the Hall-Héroult process. 
Table 10 Possible combination of measures for electrolysis. $X$ means that a combination is possible. - means that the measures are mutually exclusive.

\begin{tabular}{|c|c|c|c|c|c|c|c|c|c|c|c|c|c|c|c|c|c|c|c|c|}
\hline & 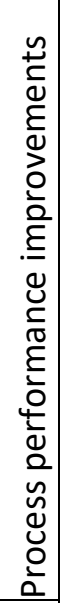 & 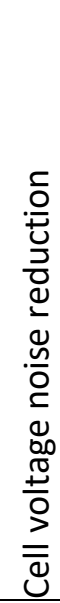 & 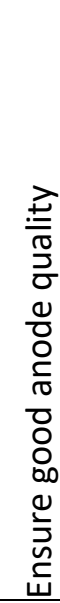 & 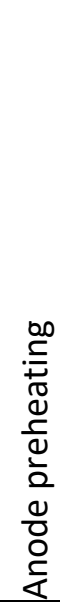 & 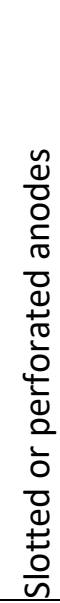 & 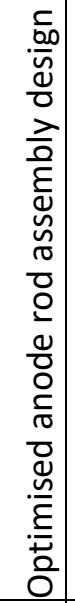 & 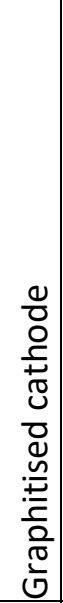 & 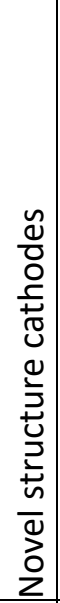 & 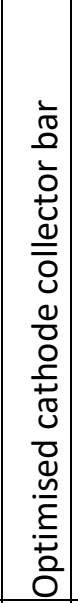 & 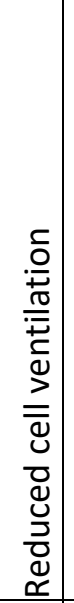 & 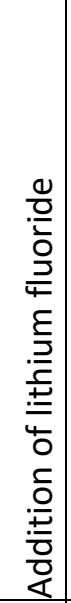 & 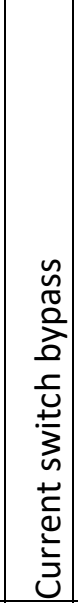 & 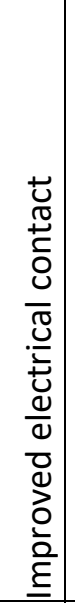 & 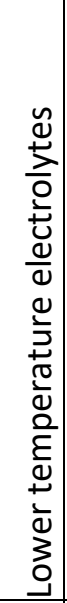 & 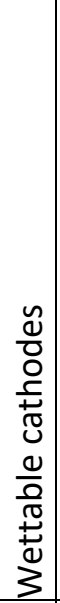 & 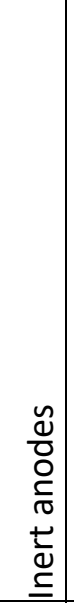 & $\begin{array}{l}\tilde{y} \\
\frac{0}{0} \\
0 \\
\frac{C}{0} \\
\tilde{0} \\
\mathbb{0} \\
0\end{array}$ & 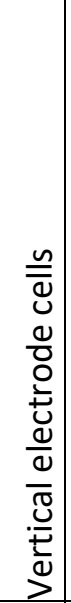 & 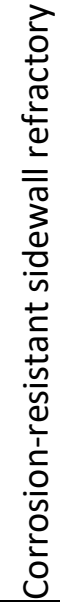 & 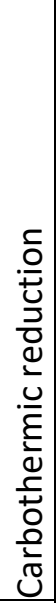 \\
\hline $\begin{array}{l}\text { Process } \\
\text { performa } \\
\text { nce } \\
\text { improve } \\
\text { ments }\end{array}$ & & $x$ & $X$ & $x$ & $x$ & $\mathrm{X}$ & $x$ & $x$ & $x$ & $x$ & $x$ & $x$ & $x$ & $x$ & $x$ & $x$ & $x$ & $x$ & $x$ & - \\
\hline $\begin{array}{l}\text { Cell } \\
\text { voltage } \\
\text { noise } \\
\text { reductio } \\
\mathrm{n}\end{array}$ & $X$ & & $X$ & $X$ & $X$ & $X$ & $X$ & $X$ & $X$ & $X$ & $X$ & $X$ & $X$ & $X$ & $X$ & $X$ & $X$ & $X$ & $X$ & - \\
\hline $\begin{array}{l}\text { Ensure } \\
\text { good } \\
\text { anode } \\
\text { quality }\end{array}$ & $X$ & $X$ & & $X$ & $X$ & $X$ & $X$ & $x$ & $X$ & $X$ & $X$ & $X$ & $X$ & $X$ & $X$ & $X$ & $X$ & $X$ & $X$ & - \\
\hline $\begin{array}{l}\text { Anode } \\
\text { preheati } \\
\text { ng }\end{array}$ & $X$ & $X$ & $X$ & & $X$ & $X$ & $X$ & $X$ & $X$ & $X$ & $X$ & $X$ & $x$ & $X$ & $X$ & $X$ & $X$ & $X$ & $x$ & - \\
\hline $\begin{array}{l}\text { Slotted } \\
\text { or } \\
\text { perforate } \\
\text { d anodes }\end{array}$ & $X$ & $X$ & $X$ & $X$ & & $X$ & $X$ & $X$ & $X$ & $X$ & $X$ & $X$ & $X$ & $X$ & $X$ & $X$ & $X$ & $X$ & $X$ & - \\
\hline $\begin{array}{l}\text { Optimise } \\
\text { d anode } \\
\text { rod } \\
\text { assembly } \\
\text { design }\end{array}$ & $x$ & $X$ & $X$ & $X$ & $X$ & & $X$ & $X$ & $X$ & $x$ & $X$ & $X$ & $X$ & $X$ & $X$ & $x$ & $X$ & $X$ & $X$ & - \\
\hline $\begin{array}{l}\text { Graphitis } \\
\text { ed } \\
\text { cathode }\end{array}$ & $X$ & $X$ & $X$ & $X$ & $X$ & $X$ & & $X$ & $X$ & $X$ & $X$ & $X$ & $X$ & $X$ & $X$ & $x$ & $X$ & $X$ & $X$ & - \\
\hline $\begin{array}{l}\text { Novel } \\
\text { structure } \\
\text { cathodes }\end{array}$ & $x$ & $X$ & $X$ & $X$ & $x$ & $X$ & $X$ & & $X$ & $X$ & $X$ & $X$ & $X$ & $X$ & $X$ & $x$ & $X$ & $X$ & $x$ & - \\
\hline $\begin{array}{l}\text { Optimise } \\
\text { d } \\
\text { cathode }\end{array}$ & $x$ & $X$ & $X$ & $X$ & $X$ & $X$ & $X$ & $x$ & & $X$ & $X$ & $X$ & $X$ & $X$ & $X$ & $x$ & $X$ & $X$ & $x$ & - \\
\hline
\end{tabular}




\begin{tabular}{|c|c|c|c|c|c|c|c|c|c|c|c|c|c|c|c|c|c|c|c|c|}
\hline $\begin{array}{l}\text { collector } \\
\text { bar } \\
\text { structure }\end{array}$ & & & & & & & & & & & & & & & & & & & & \\
\hline $\begin{array}{l}\text { Reduced } \\
\text { cell } \\
\text { ventilatio } \\
\mathrm{n}\end{array}$ & $X$ & $X$ & $x$ & $X$ & $X$ & $x$ & $X$ & $X$ & $X$ & & $X$ & $X$ & $X$ & $X$ & $X$ & $X$ & $X$ & $X$ & $X$ & - \\
\hline $\begin{array}{l}\text { Addition } \\
\text { of } \\
\text { lithium } \\
\text { fluoride }\end{array}$ & $X$ & $X$ & $X$ & $X$ & $X$ & $x$ & $X$ & $X$ & $X$ & $X$ & & $X$ & $X$ & $X$ & $X$ & $X$ & $X$ & $X$ & $X$ & - \\
\hline $\begin{array}{l}\text { Current } \\
\text { switch } \\
\text { bypass }\end{array}$ & $X$ & $x$ & $X$ & $x$ & $x$ & $x$ & $x$ & $x$ & $x$ & $x$ & $x$ & & $x$ & $x$ & $x$ & $x$ & $x$ & $X$ & $x$ & - \\
\hline $\begin{array}{l}\text { Improve } \\
\text { d } \\
\text { electrical } \\
\text { contact }\end{array}$ & $X$ & $x$ & $x$ & $X$ & $X$ & $x$ & $X$ & $x$ & $X$ & $X$ & $X$ & $X$ & & $x$ & $x$ & $X$ & $x$ & $x$ & $x$ & - \\
\hline $\begin{array}{l}\text { Lower } \\
\text { temperat } \\
\text { ure } \\
\text { electrolyt } \\
\text { es }\end{array}$ & $x$ & $X$ & $x$ & $x$ & $X$ & $X$ & $x$ & $X$ & $X$ & $X$ & $x$ & $X$ & $x$ & & $X$ & $x$ & $x$ & $X$ & $X$ & - \\
\hline $\begin{array}{l}\text { Wettable } \\
\text { cathodes }\end{array}$ & $X$ & $X$ & $x$ & $X$ & $X$ & $x$ & $X$ & $X$ & $X$ & $x$ & $X$ & $X$ & $X$ & $X$ & & $X$ & $X$ & $X$ & $X$ & - \\
\hline $\begin{array}{l}\text { Inert } \\
\text { anodes }\end{array}$ & $X$ & $X$ & $X$ & $X$ & $X$ & $X$ & $X$ & $X$ & $X$ & $X$ & $X$ & $x$ & $x$ & $X$ & $X$ & & $x$ & $X$ & $X$ & - \\
\hline $\begin{array}{l}\text { Gas } \\
\text { anodes }\end{array}$ & $x$ & $x$ & $X$ & $X$ & $X$ & $X$ & $X$ & $X$ & $X$ & $x$ & $X$ & $x$ & $x$ & $x$ & $X$ & $X$ & & $x$ & $X$ & - \\
\hline $\begin{array}{l}\text { Vertical } \\
\text { electrode } \\
\text { cells }\end{array}$ & $x$ & $X$ & $X$ & $x$ & $x$ & $X$ & $X$ & $X$ & $x$ & $x$ & $x$ & $x$ & $x$ & $X$ & $x$ & $x$ & $x$ & & $x$ & - \\
\hline $\begin{array}{l}\text { Corrosio } \\
\mathrm{n} \text { - } \\
\text { resistant } \\
\text { sidewall } \\
\text { refractor } \\
\text { y }\end{array}$ & $X$ & $X$ & $x$ & $X$ & $X$ & $x$ & $X$ & $X$ & $X$ & $x$ & $x$ & $X$ & $X$ & $X$ & $X$ & $x$ & $x$ & $x$ & & - \\
\hline $\begin{array}{l}\text { Carbothe } \\
\text { rmic } \\
\text { reductio } \\
\text { n }\end{array}$ & - & - & - & - & - & - & - & - & - & - & - & - & - & - & - & - & - & - & - & \\
\hline
\end{tabular}

Table 11 shows a compilation of the energy saving potentials for the measures for electrolysis. Note that the direct retrofit of inert anodes has a negative potential saving, implying that the energy need increases for electrolysis. However, when taking into account the energy demand for producing the anodes, there is a potential energy saving. As can be seen in Table 10, all measures for the HallHéroult process can be combined, which implies that the highest savings potential for the HallHéroult process can be achieved by combining the measures. It is unknown how this combination 
compares to the carbothermic reduction, since the savings potential is lower than the sum of the potentials for the individual measures, and no savings potential for the combination was found in the literature.

Table 11 Compilation of the energy saving potentials for the measures for electrolysis. - means that no energy saving potential was found.

\begin{tabular}{|c|c|c|}
\hline Measure & Energy saving potential & References \\
\hline \multicolumn{3}{|l|}{ Process performance improvements } \\
\hline $\begin{array}{l}\text { - Fuzzy controller with mathematical } \\
\text { model for process temperature }\end{array}$ & $0.6 \mathrm{kWh} / \mathrm{kg} \mathrm{Al}$ & {$[41]$} \\
\hline $\begin{array}{ll}\text { - } & \text { Improved cell control point-feeding } \\
\text { systems of existing PFPB cells }\end{array}$ & $0.2 \mathrm{kWh} / \mathrm{kg} \mathrm{Al}$ & [6] \\
\hline - $\quad$ Generation 2 control system & $0.4 \mathrm{kWh} / \mathrm{kg} \mathrm{Al}$ & {$[44]$} \\
\hline - $\quad$ Generation 3 control system & $0.355 \mathrm{kWh} / \mathrm{kg} \mathrm{Al}$ & {$[44]$} \\
\hline Cell voltage noise reduction & - & \\
\hline Ensure good anode quality & - & \\
\hline Anode preheating & $0.04 \mathrm{kWh} / \mathrm{kg} \mathrm{Al}$ & [52] \\
\hline Slotted or perforated anodes & $0.781 \mathrm{kWh} / \mathrm{kg} \mathrm{Al}$ & [53] \\
\hline Optimised anode rod assembly design & - & \\
\hline Graphitised cathode & - & \\
\hline Novel structure cathodes & $0.56-1 \mathrm{kWh} / \mathrm{kg} \mathrm{Al}$ & {$[54,58,59]$} \\
\hline Optimised cathode collector bar structure & $0.738 \mathrm{kWh} / \mathrm{kg} \mathrm{Al}$ & [60] \\
\hline Reduced cell ventilation & - & \\
\hline - Distributed pot suction system & $0.4 \mathrm{kWh} / \mathrm{kg} \mathrm{Al}$ & [63] \\
\hline Addition of lithium fluoride (LiF) & - & \\
\hline Current switch bypass & - & \\
\hline Improved electrical contact & - & \\
\hline Lower temperature electrolytes & - & \\
\hline Wettable cathodes & $0.4-3.1 \mathrm{kWh} / \mathrm{kg} \mathrm{Al}$ & {$[92,95,97,101]$} \\
\hline \multicolumn{3}{|l|}{ Inert anodes } \\
\hline - Electrolysis with direct retrofit & $-2.85-0 \mathrm{kWh} / \mathrm{kg} \mathrm{Al}$ & [103] \\
\hline $\begin{array}{ll}\text { - } & \text { Electrolysis + anode production with } \\
\text { direct retrofit }\end{array}$ & $1 \mathrm{kWh} / \mathrm{kg} \mathrm{Al}$ or $7 \%$ & [103] \\
\hline $\begin{array}{ll}\text { - } & \text { Electrolysis with inert anodes and } \\
\text { wettable cathodes }\end{array}$ & $25 \%$ & [99] \\
\hline $\begin{array}{l}\text { - Electrolysis with inert anodes and } \\
\text { wettable cathodes }\end{array}$ & $\begin{array}{l}2.4 \mathrm{kWh} / \mathrm{kg} \text { Al during anode } \\
\text { production + a saving during } \\
\text { electrolysis from using } \\
\text { wettable cathodes }\end{array}$ & {$[90]$} \\
\hline Gas anodes & - & \\
\hline Vertical electrode cells & $4 \mathrm{kWh} / \mathrm{kg} \mathrm{Al}$ or $25-30 \%$ & [105] \\
\hline Corrosion-resistant sidewall refractory & - & \\
\hline \multicolumn{3}{|l|}{ Carbothermic reduction } \\
\hline - $\quad$ Direct carbothermic reduction & $15.4-51.3 \%$ & {$[7,101,111,115]$} \\
\hline - Indirect carbothermic reduction & - & \\
\hline
\end{tabular}


Inert anodes are considered in combination with wettable cathodes or low-temperature electrolytes. This is due to the fact that inert anodes are expected to increase cell energy use over conventional technology [105] or that, at best, they remain approximately unchanged [103].

As mentioned above, the development of inert anodes experiences problems due to the high temperatures and corrosivity of the conventional electrolytes. Both Tian et al. [123] and Tkacheva et al. [124] raise low-temperature electrolytes for aluminium electrolysis as one possible way to substantially decrease the corrosion rate of and increase the use of inert anodes. Their articles focus on electrolytes based on potassium cryolite, but the argument should hold for the electrolytes based on ionic liquids as well. Sadoway [125] highlights the potential benefit of the lower chemical attack rate which a lower operating temperature entails. According to Zheng et al. [87], aluminium electrolysis with ionic liquids and inert anodes has not yet been a subject of systematic research. There are a few articles studying inert anodes with potassium cryolite-based electrolytes (see [126, 127]) as well as sodium and potassium cryolite-based electrolytes (see [123, 128-131]).

A disadvantage of the (direct) carbothermic reduction is the large amount of bio-coke required to replace today's aluminium production [56] in order to discontinue the dependence on fossil coal. Biomass can be seen as a limited resource, and aluminium production has to compete with a wide range of other applications. In the worst case, the continued dependence on fossil coal can have financial risks in a future where the global demand for fossil coal increases while the global reserves decline.

Using an electrolysis cell with inert anodes, wettable cathodes, low-temperature electrolytes and vertical electrodes will eliminate the process-related GHG emissions and reduce energy use. Further energy reductions can be achieved by implementing the other measures presented in Table 11. Combining this with electricity with low or no GHG emissions can result in an almost carbon-neutral electrolysis. At the same time, the reduced energy use can strengthen the competitiveness of the aluminium industry. There will also be a lowered dependence on coal, since the anodes will no longer be consumed in the process. The coal dependence may be eliminated depending on what materials that will be used for inert anodes, wettable cathodes and corrosion-resistant sidewall refractory. However, all these benefits will require further research and development for the measures designated as novel or emerging.

\subsubsection{Recycling}

The best energy efficiency measure would probably be to replace primary with secondary aluminium production, which provides a savings potential of at least $95 \%$. However, this requires enough postconsumer scrap to be available, which might not be the case today. Another way to increase the amount of secondary aluminium produced is through increased recovery yields.

Table 12 shows which of the measures for recycling can possibly be combined. Some of the presented measures concern recycling in furnaces, and the combination of these measures depends mainly on the furnace type used and which part of the furnace the measure affects. Recycling through hot extrusion or SPS would replace conventional recycling through remelting in furnaces. This implies that these two technologies are mutually exclusive both with respect to each other and to most of the measures associated with remelting in furnaces. Melting cleaned scrap and an internal burner system may not be possible to combine, since cleaned scrap eliminates the organic compounds in the gas that the internal burner system is designed to burn off. Mixing the furnace 
content in a tilting rotary furnace is achieved by rotating the entire furnace chamber, which eliminates the need for a metal pumping or stirring system. There are different methods which could be used to recover components from skimming, dross and salt slag, and therefore, combinations with other energy efficiency measures are hard to specify. However, recycling through hot extrusion and SPS will not be applicable, since there are other components than metallic aluminium in skimmings, dross and salt slag. Selecting appropriate melting furnaces and feed material and melting cleaned scrap are based on recycling in furnaces, but the principles are relevant to recycling through hot extrusion and SPS as well. Recycling of small scrap, such as chips and filings, is better done through hot extrusion and SPS than with conventional remelting, due to the reduced material loss.

Table 12 Possible combination of energy efficiency measures for recycling. X means that a combination is possible. - means that the measures are mutually exclusive. ? means that a possible combination unknown.

\begin{tabular}{|c|c|c|c|c|c|c|c|c|c|c|}
\hline & 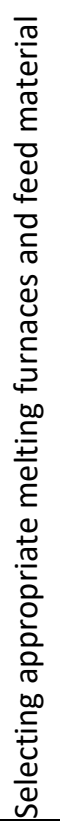 & 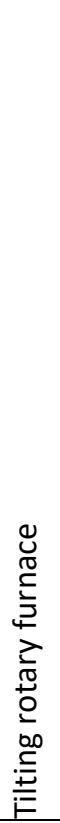 & 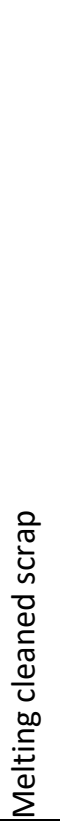 & 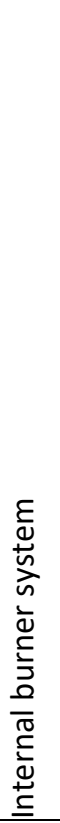 & 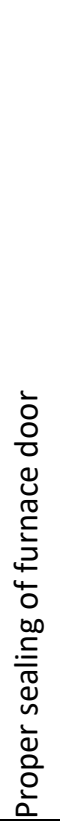 & 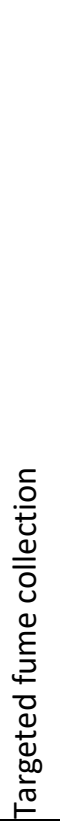 & 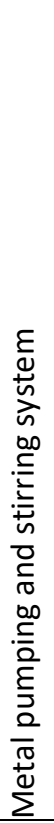 & 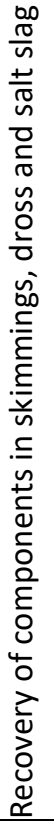 & 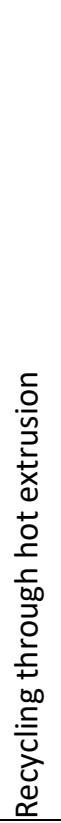 & 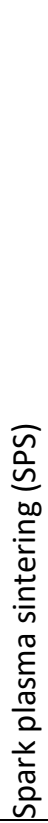 \\
\hline $\begin{array}{l}\text { Selecting appropriate melting furnaces and feed } \\
\text { material }\end{array}$ & & $\mathrm{X}$ & $\mathrm{X}$ & $\mathrm{X}$ & $x$ & $\mathrm{X}$ & $\mathrm{X}$ & $\mathrm{X}$ & $\mathrm{X}$ & $\mathrm{X}$ \\
\hline Tilting rotary furnace & $\mathrm{X}$ & & $\mathrm{X}$ & $\mathrm{X}$ & $\mathrm{X}$ & $\mathrm{X}$ & - & $?$ & - & - \\
\hline Melting cleaned scrap & $\mathrm{X}$ & $\mathrm{X}$ & & - & $\mathrm{x}$ & $\mathrm{X}$ & $\mathrm{X}$ & $?$ & $\mathrm{X}$ & $\mathrm{X}$ \\
\hline Internal burner system & $\mathrm{X}$ & $\mathrm{X}$ & - & & $\mathrm{X}$ & $\mathrm{X}$ & $\mathrm{X}$ & $?$ & - & - \\
\hline Proper sealing of furnace door & $\mathrm{X}$ & $\mathrm{X}$ & $\mathrm{X}$ & $\mathrm{X}$ & & $\mathrm{X}$ & $\mathrm{X}$ & $\mathrm{X}$ & - & - \\
\hline Targeted fume collection & $\mathrm{X}$ & $\mathrm{X}$ & $\mathrm{X}$ & $\mathrm{X}$ & $\mathrm{X}$ & & $\mathrm{X}$ & $\mathrm{X}$ & - & - \\
\hline Metal pumping and stirring system & $\mathrm{X}$ & - & $\mathrm{X}$ & $\mathrm{X}$ & $\mathrm{X}$ & $\mathrm{X}$ & & $?$ & - & - \\
\hline $\begin{array}{l}\text { Recovery of components in skimmings, dross and } \\
\text { salt slag }\end{array}$ & $\mathrm{x}$ & $?$ & $?$ & $?$ & $\mathrm{x}$ & $\mathrm{X}$ & $?$ & & - & - \\
\hline Recycling through hot extrusion & $\mathrm{X}$ & - & $\mathrm{X}$ & - & - & - & - & - & & - \\
\hline Spark plasma sintering (SPS) & $x$ & - & $x$ & - & - & - & - & - & - & \\
\hline
\end{tabular}

Table 13 shows a compilation of energy saving potentials for efficiency measures for recycling. As seen in Table 12, many of the measures can be combined, which implies that the highest savings potential can be achieved by combining the measures. However, it is worth remembering that recycling through hot extrusion and SPS are better suited for smaller scrap and may not be applicable to larger scrap. This may make the savings potential for recycling through hot extrusion and SPS irrelevant for the recycling of larger scrap. To a large extent, the chosen recycling technique 
is based on the scrap type which is recycled on each site, and the chosen technique may be less suitable for other scrap types. This may affect the energy saving potential which is achievable in each case.

Table 13 Compilation of the energy saving potentials for the measures for recycling. - means that no energy saving potential was found.

\begin{tabular}{|l|l|l|}
\hline Measure & Energy saving potential & References \\
\hline $\begin{array}{l}\text { Selecting appropriate melting and } \\
\text { feed material }\end{array}$ & Up to $1 \mathrm{kWh} / \mathrm{kg} \mathrm{Al}$ & {$[8]$} \\
\hline Tilting rotary furnace & - & \\
\hline Melting cleaned scrap & - & \\
\hline Internal burner system & - & \\
\hline Proper sealing of furnace door & - & \\
\hline Targeted fume collection & - & \\
\hline Metal pumping and stirring system & - & \\
\hline $\begin{array}{l}\text { Recovery of components in } \\
\text { skimmings, dross and salt slag }\end{array}$ & - & \\
\hline Recycling through hot extrusion & $90 \%$ & {$[74]$} \\
\hline Spark plasma sintering (SPS) & $90-95 \%$ compared to hot pressing sintering & {$[116]$} \\
\hline
\end{tabular}

\subsubsection{Casting, rolling, extrusion, heat treatment and anodising}

Table 14 shows which of the measures for casting can possibly be combined. CRIMSON casting is a shape-casting method, while electromagnetic casting, as mentioned above, has been used for the casting of ingots and billets. However, electromagnetic casting can be used for die casting as well (see e.g. [132] and [133]), so CRIMSON casting and electromagnetic casting can possibly complement each other. Some of the other measures can be combined, since they affect different parts of the casting operations. It is uncertain whether CRIMSON casting can be combined with supplying molten aluminium for direct moulding or with improved practices for molten metal transfer, because it is unknown which methods can be utilised to supply the metal to the CRIMSON casting system.

Table 14 Possible combination of measures for casting. X means that a combination is possible. ? means that a possible combination unknown.

\begin{tabular}{|c|c|c|c|c|c|}
\hline & 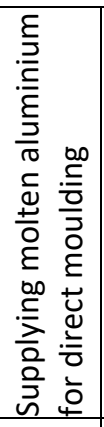 & $\begin{array}{l}\frac{n}{0} \\
\frac{0}{0} \\
0 \\
00 \\
. \frac{.0}{00} \\
\frac{0}{\pi} \\
\frac{0}{2}\end{array}$ & 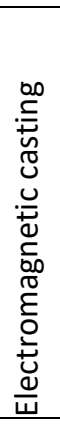 & 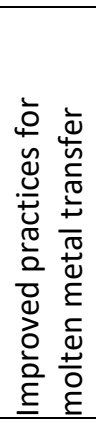 & 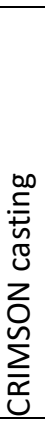 \\
\hline Supplying molten aluminium for direct moulding & & $x$ & $\mathrm{X}$ & $\mathrm{X}$ & ? \\
\hline Arranging orders & $\mathrm{X}$ & & $\mathrm{x}$ & $\mathrm{x}$ & $\mathrm{x}$ \\
\hline Electromagnetic casting & $\mathrm{x}$ & $\mathrm{x}$ & & $\mathrm{x}$ & $\mathrm{x}$ \\
\hline Improved practices for molten metal transfer & $\mathrm{x}$ & $\mathrm{X}$ & $\mathrm{x}$ & & ? \\
\hline CRIMSON casting & ? & $\mathrm{x}$ & $\mathrm{x}$ & ? & \\
\hline
\end{tabular}


Table 15 shows a compilation of the energy saving potentials for energy efficiency measures for casting. As seen in Table 14, many of the measures can be combined, which implies that the highest saving potential can be achieved by combining the measures. The saving potential may depend on the casting technique used.

Table 15 Compilation of the energy saving potentials for energy efficiency measures for casting. - means that no energy saving potential was found.

\begin{tabular}{|l|l|l|}
\hline Measure & Energy saving potential & References \\
\hline $\begin{array}{l}\text { Supplying molten aluminium for direct } \\
\text { moulding }\end{array}$ & $1 \mathrm{kWh} / \mathrm{kg} \mathrm{Al}$ & {$[3]$} \\
\hline Arranging orders & - & \\
\hline Electromagnetic casting & - & \\
\hline Improved practices for molten metal transfer & - & \\
\hline CRIMSON casting & $64 \%$ when producing filter housing & {$[117]$} \\
& $1.3-7.19 \mathrm{kWh} / \mathrm{kg} \mathrm{Al}$ & {$[118,119]$} \\
\hline
\end{tabular}

Since alloys of the Al-Cu-Mn-Zr system still need hot rolling [120], it may be possible to roll these alloys with the combined casting and rolling method. Combined casting and rolling has an energy saving potential of $25 \%$ [7]. The combination of the two measures can achieve a higher savings potential.

No energy saving potentials for extrusion, heat treatment and anodising were found in the literature. Only one energy efficiency measure was found for extrusion, namely isothermal extrusion. Heat treatment based on the casting method and HAT and CAT technologies are mutually exclusive, since these measures are based on specific heat treatment technologies and only one of them is chosen when conducting the heat treatment. Microwave heat treatment employs microwave heating instead of conventional furnaces, and the combination of microwave heating with the technology in the other measures is hard to specify. The new sealing methods for anodising can readily be combined with the general measure of reducing heat losses, which can provide higher energy savings.

\section{Conclusions}

In total, 52 energy efficiency measures were identified, whereof the majority addressed electrolysis, recycling and general measures. This can be explained by the high energy intensity of electrolysis, the relatively wide applicability of the general measures and the fact that all aluminium passes through either electrolysis or recycling. Electrolysis shows a higher number of emerging/novel measures compared to the other processes, a fact which can also be explained by the high energy intensity. In many cases, the presented measures can be combined, which implies that the best solution should be to combine the measures in order to achieve the greatest energy efficiency improvement. However, for recycling, the energy saving potential may depend on the scrap type recycled and on the recycling technique used.

Primary aluminium production is today characterised by high energy demand and GHG emissions, where the electrolysis is one of the most energy- and GHG-intensive processes. It is possible to lower the energy intensity by implementing both currently available and novel energy efficiency measures. 
There may also be a future prospect for achieving carbon-neutral and coal-independent electrolysis. However, this will require further research into and development of the measures designated as novel or emerging. Additionally, a combination of several of the novel/emerging measures is needed to ensure reduced energy use. Low-temperature electrolytes can be a helping factor in the implementation of inert anodes. Challenges may occur with respect to carbothermic reduction, in that bio-coke may be insufficient to supply the carbon for the reaction, while at the same time, the global fossil coal reserves are declining. It is also uncertain how the energy use for a Hall-Héroult cell incorporating all measures presented in this article compares to the energy use for the carbothermic reduction.

Secondary aluminium production will be increasingly important to meet the increasing demand for aluminium. Producing secondary aluminium requires only $5 \%$ of the energy compared to primary aluminium. This will be important in respects to environmental and economic concerns and strengthened competitiveness. Focusing on increased secondary production and recovery yields as well as on reduced energy use in secondary production will be pivotal. Further research and development will be needed regarding, for example, novel recycling methods to recover smaller scrap. Recycling through hot extrusion and spark plasma sintering are methods better suited to smaller scrap, such as chips and filings.

Processing of aluminium with extrusion, rolling, casting (shape-casting and casting of ingots, slabs and billets), heat treatment and anodising will also benefit from energy efficiency. These processes showed a fewer number of measures, which might be explained by the fact that to some extent, these processes do not demand as much energy compared, for example, to electrolysis. It is worth remembering the general measures presented in the paper, which have a wide applicability for most production processes.

\section{Acknowledgements}

This work has been financed by the Swedish Energy Agency (project number 40552-1). We appreciate the valuable information received from the Swedish Aluminium Association. We would like to thank our colleagues at the Division of Energy Systems at Linköping University for their valuable comments on the article draft.

\section{References}

[1] Cullen JM, Allwood JM. Mapping the global flow of aluminum: from liquid aluminum to end-use goods. Environ Sci Technol 2013;47:3057-64.

[2] Milford RL, Allwood JM, Cullen JM. Assessing the potential of yield improvements, through process scrap reduction, for energy and $\mathrm{CO}_{2}$ abatement in the steel and aluminium sectors. Resour, Conserv and Recycl 2011;55:1185-95.

[3] European Integrated Pollution Prevention and Control Bureau. Best available technique (BAT) reference document for the non-ferrous metals industries. Seville: European Commission's Joint Research Centre; 2014.

[4] European Integrated Pollution Prevention and Control Bureau. Reference document on best available techniques in the smitheries and foundries industry. Seville: European Commission's Joint Research Centre; 2005. 
[5] European Integrated Pollution Prevention and Control Bureau. Reference document on best available techniques for the surface treatment of metals and plastics. Seville: European Commission's Joint Research Centre; 2006.

[6] Kermeli K, ter Weer PH, Crijns-Graus W, Worrell E. Energy efficiency improvement and GHG abatement in the global production of primary aluminium. Energy Effic 2015;8:629-66.

[7] BCS (Brown Construction Services Inc.). U.S. energy requirements for aluminum production: historical perspective, theoretical limits and current practices. Washington DC: U.S. Department of Energy; 2007.

[8] Tabereaux AT, Peterson RD. Aluminum production. In: Seetharaman S, McLean A, Guthrie R, Sridhar S, editors. Treatise on process metallurgy: industrial processes, volume 3, Oxford \& Waltham: Elsevier Ltd.; 2014, p. 839-917.

[9] aluminum-production.com. Detailed description of a cell and its basic functioning. http://www.aluminum-production.com/Basic functioning.html; n.d. [Accessed 17.03.01].

[10] International Aluminium Institute. Primary aluminium smelting energy intensity. http://www.world-aluminium.org/statistics/primary-aluminium-smelting-energy-intensity/; 2016 [Accessed 17.03.02].

[11] Schmitz C. Handbook of aluminium recycling: fundamentals mechanical preparation metallurgical processing plant design. Essen: Vulkan-Verlag GmbH; 2006.

[12] Shinzato MC, Hypolito R. Solid waste from aluminum recycling process: characterization and reuse of its economically valuable constituents. Waste Manag 2005;25:37-46.

[13] Tsakiridis PE. Aluminium salt slag characterization and utilization - a review. J Hazard Mater 2012;217-218:1-10.

[14] Rajkumar K, Rajan P, Charles JMA. Microwave heat treatment on aluminium 6061 alloy-boron carbide composites. Procedia Eng 2014;34-41.

[15] Zhao R, Nowicki C, Gosselin L, Duchesne C. Energy and exergy inventory in aluminum smelter from a thermal integration point-of-view. Int J Energy Res 2016;40:1321-38.

[16] Sørhuus AK, Ose S, Nilsen BM. Possible use of $25 \mathrm{MW}$ thermal energy recovered from the potgas at Alba line 4. In: Hyland M, editor. TMS Light metals, Hoboken, New Jersey: John Wiley \& Sons, Inc.; 2015, p. 631-6.

[17] Fanisalek H, Bashiri M, Kamali R. Aluminum smelter waste heat recovery plant (heat exchangers fouling and corrosion-a detailed investigation). In: Salazar-Villalpando MD, Neelameggham NR, Post Guillen D, Pati S, Krumdick GK, editors. Energy technology 2012: carbon dioxide management and other technologies, Hoboken, New Jersey: John Wiley \& Sons, Inc.; 2012;203-14.

[18] Nowicki C, Gosselin L. An overview of opportunities for waste heat recovery and thermal integration in the primary aluminum industry. JOM 2012;64:990-6.

[19] Guo L, Wang Z, Li J. Three-dimensional thermal field analysis of a novel aluminum reduction cell with a lava thermo-exchanger. In: Proceedings of 2010 world non-grid-connected wind power and energy conference, WNWEC 2010, p. 241-4.

[20] Barzi YM, Assadi M. Evaluation of a thermosyphon heat pipe operation and application in a waste heat recovery system. Exp Heat Transf 2015;28:493-510.

[21] White DW. Furnaces designed for fuel efficiency. In: Lindsay, SJ, editor. Light metals 2011, Switzerland: Springer International Publishers; 2011, p. 1165-72.

[22] Hemrick JG, Rodrigues-Schroer A, Colavito D, Smith JD. Improved furnace efficiency through the use of refractory materials. In: Lindsay, SJ, editor. Light metals 2011, Switzerland: Springer International Publishers; 2011, p. 1211-6.

[23] Ighodalo $\mathrm{OA}$, Ajuwa $\mathrm{Cl}$. Heat balance determination for a gas-fired furnace for melting nonferrous metals. Res J Appl Sci, Eng Technol 2011;3:471-3.

[24] Hassan MI, Al Kindi R. Feasibility study of regenerative burners in aluminum holding furnaces. JOM 2014;66:1603-11. 
[25] Ajdari HRB, Sadrameli SM. Theoretical and experimental studies of a thermal regenerator for heat recovery in aluminum melting furnaces. In: Hyland M, editor. TMS Light metals 2015, Hoboken, New Jersey: John Wiley \& Sons, Inc.; 2015, p. 439-43.

[26] Villar A, Arribas JJ, Parrondo J. Waste-to-energy technologies in continuous process industries. Clean Technol and Environ Policy 2012;14:29-39.

[27] Bright MA, Chandler RC, Henderson RS, Starczewski RJ. Recent developments in molten metal pumps to enhance reverberatory furnace productivity. Alum Int Today 2007;19:18-22.

[28] Peel AM, Herbert J, Roth D, Collins MJ. Furnace operations to reduce dross generation. Mater Sci Forum 2010, p. 45-52.

[29] Hassan MI, Brimmo AT. CFD comparison of immersed heater and open fire burner designs for casting furnaces. In: Hyland M, editor. TMS light metals, Hoboken, New Jersey: John Wiley \& Sons, Inc.; 2015, p. 915-20.

[30] Liu G, Bangs CE, Müller DB. Unearthing Potentials for decarbonizing the U.S. aluminum cycle. Environ Sci \& Technol 2011;45:9515-22.

[31] D'Ettorre A, Giudici R, Tasca A, Visus J, Benavides VG, Kobayashi WT. Low dross generation with oxy-fuel system. Metall Ital. 2007;99:47-52.

[32] Zhang JQ, Zhou NJ, Zhou SH. Combustion and energy balance of aluminum holding furnace with bottom porous brick purging system. J Cent South Univ Technol (Engl Ed) 2012;19:200-5.

[33] Belt C. Current state of aluminum melting and holding furnaces in industry. JOM 2015;67:26905.

[34] Gamweger K, Bauer P. Energy savings and productivity increases at an aluminum slug plant due to bottom gas purging. In: Neelameggham NR, Reddy R G., Belt CK, Vidal EE, editors. Energy technology perspectives, Warrendale: TMS; 2009, p. 169-71.

[35] Chandler RC, Shull PD. Increasing the surface emissivity of aluminum shapes to improve radiant heat transfer. In: Resnick, PJ, editor. Light metals 2009, Warrendale: TMS; 2009, p. 713-6.

[36] Allwood JM, Ashby MF, Gutowski TG, Worrell E. Material efficiency: a white paper. Resour, Conserv Recycl 2011;55:362-81.

[37] Zhang W, Wong D, Gilbert M, Gao Y, Dorreen M, Taylor M, et al. Reduction of anode effect duration in 400kA prebake cells. In: Lindsay, SJ, editor. TMS Light metals 2011, Switzerland: Springer International Publishers; 2011, p. 319-23.

[38] Santos H, Melo D, Calixto J, Santos J, Miranda J. Reduction of PFC emissions at pot line $70 \mathrm{kA}$ of Companhia Brasileira de Alumínio. In: Lindsay, SJ, editor. Light metals 2011, Switzerland: Springer International Publishers; 2011, p. 281-4.

[39] Cao D, Song X, Li J. Research on statistical process control for aluminium electrolysis reduction. In: Yarlagadda P, Kim Y-H, editors. Appl Mechanics and Mater, vols. 241-244, Zurich, Switzerland: Trans Tech Publications Ltd.; 2013, p. 1839-44.

[40] Jiejia L, Shitao L, Zhichao F. The research of fault diagnosis in aluminum electrolysis based on rough set. Proceedings - ISECS International Colloquium on Computing, Communication, Control, and Management, CCCM 2008, p. 162-6.

[41] Zeng S, Li J, Ren X, Zhao Z. Fuzzy control with prediction of temperature in 300ka aluminum production pot lines. Proceedings of the IASTED International Conference on Modelling, Identification and Control, 2010, p. 93-8.

[42] Braga CAP, da Fonseca Netto JV. A dynamic state observer to control the energy consumption in aluminium production cells. Syst Sci and Control Eng 2016;4:307-19.

[43] Kolås $S$, Wasb $\varnothing S O$. A nonlinear model based control strategy for the aluminium electrolysis process. In: Johnson, JA, editor. TMS Light metals 2010, Seattle, WA: Minerals, Metals and Materials Society; 2010, p. 501-5.

[44] Mulder A, Gao Y, Zhou D, Wong DS, Ming L, Lavoie P, et al. New generation control for daily aluminium smelter improvement generation 3 process control for potlines. In: Grandfield, J, editor. TMS Light metals 2014, Switzerland: Springer International Publishers; 2014, p. 835-40. 
[45] Banta L, Dai C, Biedler P. Noise classification in the aluminum reduction process. In: Bearne G, Dupuis $\mathrm{M}$, Tarcy $\mathrm{G}$, editors. Essential readings in light metals volume 2: aluminium reduction technology, Hoboken, New Jersey: John Wiley \& Sons, Inc.; 2013, p. 812-6.

[46] Agnihotri A, Pathak SU, Mukhopadhyay J. Cell voltage noise in aluminium smelting. Trans Indian Inst Met 2014;67:275-83.

[47] Agnihotri A, Pathak SU, Mukhopadhyay J. Effect of metal pad instabilities on current efficiency in aluminium electrolysis. Transactions of the Indian Institute of Metals 2014;67:315-23.

[48] Agnihotri A, Pathak SU, Mukhopadhyay J. Metal instabilities and its effect on cell performance during aluminium smelting. In: Abhilash, Pandey BD, Mankhand TR, editors. 17th International Conference on Nonferrous Minerals and Metals, Ranchi, India: Trans Tech Publications; 2014. p. 4554.

[49] Naixiang F, Jianping P, Qingren N, Lei Z, Ning K, Xian'an L, et al. Towards decreasing energy consumption of aluminum reduction by using anodes with holes and channels. In: Grandfield, J, editor. TMS Light metals 2014, Switzerland: Springer International Publishers; 2014, p. 517-20. [50] Amrani S, Kocaefe D, Kocaefe Y, Morais B, Blaney G. Effect of heating rate on the crack formation during baking in carbon anodes used in aluminum industry. In: Grandfield, J, editor. TMS Light metals 2014, Switzerland: Springer International Publishers; 2014, p. 1175-80 [sch].

[51] Lange HP, Holt NJ, Linga H, Solli LN. Innovative solutions to sustainability in hydro. In: DeYoung, DH, editor. TMS Light metals 2008, p. 211-6.

[52] Fortini O, Garimella S, Kuhn E, Ruan Y, Yacob B, Sorensen J. Experimental studies of the impact of anode pre-heating. In: Suarez CE, editor. TMS Light metals 2012. Orlando, USA: John Wiley \& Sons, Inc.; 2012, p. 595-600.

[53] Tian Y, Li H, Wei L, Cao X, Yin J. Industry test of perforation anode in aluminium electrolysis technology. In: Sadler BA, editor. TMS Light metals. Light Metals 2013 - at the TMS 2013 Annual Meeting and Exhibition, San Antonio, USA: Wiley \& Sons, Inc.; 2013. p. 567-71.

[54] Feiya Y, Dupuis M, Jianfei Z, Shaoyong R. In depth analysis of energy-saving and current efficiency improvement of aluminum reduction cells. In: Sadler BA, editor. Light metals 2013, Hoboken, New Jersey: John Wiley \& Sons, Inc.; 2013, p. 537-42.

[55] Sousa I, Matos S, Paulino L, Araújo J, Costa E, Costa F, et al. Energy savings using a different anode rod design. In: Hyland M, editor. Light metals 2015, Hoboken, New Jersey: John Wiley \& Sons, Inc.; 2015, p. 691-4.

[56] Lorentsen OA. 125 years of the Hall-Héroult process-what made it a success? In: Gaune-Escard M, Haarberg GM, editors. Molten Salts Chemistry and Technology, Chichester, United Kingdom: John Wiley \& Sons Ltd.; 2014, p. 103-12.

[57] Cus Z, Sibila A. 20 Years of continues improvements in TALUM smelter. In: DeYoung, DH, editor. TMS Light metals 2008, p. 467-71.

[58] Peng J, Feng N, Feng S, Liu J, Qi X. Development and application of an energy saving technology for aluminum reduction cells. In: Lindsay, SJ, editor. TMS Light metals, Switzerland: Springer International Publishers; 2011, p. 1023-7.

[59] Naixiang F, Jianping P, Yaowu W, Yuezhong D, Xian'An L. Energy reduction technology for aluminum electrolysis: choice of the cell voltage. TMS Light metals. Light Metals 2013 - At the TMS 2013 Annual Meeting and Exhibition; 2013, p. 549-52.

[60] Dongfang Z, Xiaodong Y, Wei L. Development and application of SAMI's low voltage energysaving technology. In: Suarez CE, editor. Light metals 2012, Hoboken, New Jersey: John Wiley \& Sons, Inc.; 2012, p. 607-12.

[61] Shakhrai SG, Mikhalev YG, Kalinovskaya TG, Arkhipov GV, Kalinovskaya TG, Arkhipov GV, et al. Investigation and choice of materials for the electrical insulation of the steel bloom of an aluminum electrolyzer. Metallurgist 2016;1-7.

[62] Zhao R, Gosselin L, Fafard M, Ziegler DP. Reduced ventilation of upper part of aluminum smelting pot: potential benefits, drawbacks, and design modifications. In: Sadler BA, editor. Light metals 2013, Hoboken, New Jersey: John Wiley \& Sons, Inc.; 2013, p. 805-10. 
[63] Segatz M, Hop J, Reny P, Gikling H. Hydro's cell technology path towards specific energy consumption below 12 KWH/KG. In: Williams, E, editor. TMS Light metals 2016, Switzerland: Springer International Publishers; 2016, p. 301-5.

[64] Austreid KO. Hydro's new generation cell technology ready for action. Light Metal Age 2010;68:38-41.

[65] Tao Y, Bin C, Meng L, Xiaobing Y. Technology \& equipment for starting up \& shutting down aluminium pots under full amperage. In: Lindsay, SJ, editor. Light metals 2011, Switzerland: Springer International Publishers; 2011, p. 497-502.

[66] Von Kaenel R, Antille J, Fillet M, Lindeboom M. Non-linear behavior of a metallic foam for the reduction of energy losses at electrical contacts in the aluminum industry. In: Grandfield, J, editor. TMS Light metals 2014, Switzerland: Springer International Publishers; 2014, p. 717-22.

[67] Tsakiridis PE, Oustadakis $\mathrm{P}$, Agatzini-Leonardou S. Aluminium recovery during black dross hydrothermal treatment. J Environ Chem Eng 2013;1:23-32.

[68] Tzonev T, Lucheva B. Recovering aluminum from aluminum dross in a DC electric-arc rotary furnace. JOM 2007;59:64-8.

[69] Haase M, Tekkaya AE. Recycling of aluminum chips by hot extrusion with subsequent cold extrusion. Procedia Eng 2014;81:652-7.

[70] Wędrychowicz M, Wzorek $Ł$, Tokarski T, Noga P, Wiewióra J. Recycling without melting: an alternative approach to aluminum scrap recovery. In: Boczkal G, Perek-Nowak M, editors. 2nd International Conference on Non-Ferrous Metals, Cracow: Trans Tech Publications Ltd.; 2016, p. 284-9.

[71] Cui J, Guo W, Roven HJ, Wang Q, Chen Y, Peng T. Recycling of aluminum scrap by Severe Plastic Deformation. In: Wang, JT, Figueiredo, RB, Langdon, TG, editors. Mater Sci Forum 2011;667669:1177-82.

[72] Cui J, Roven HJ. Recycling of automotive aluminum. Trans Nonferrous Met Soc China (English Edition) 2010;20:2057-63.

[73] Haase M, Ben Khalifa N. Chip extrusion with integrated equal channel angular pressing. In: Tekkaya AE, Homberg W, Brosius A, editors. 60 Excellent Inventions in Metal Forming, Berlin: Springer Berlin Heidelberg; 2015, p. 261-6.

[74] Paraskevas D, Vanmeensel K, Vleugels J, Dewulf W, Deng Y, Duflou JR. Spark plasma sintering as a solid-state recycling technique: the case of aluminum alloy scrap consolidation. Materials 2014;7:5664-87.

[75] Ferretti I, Zanoni S, Zavanella L, Diana A. Greening the aluminium supply chain. Int J Prod Econ 2007;108:236-45.

[76] Tan RBH, Khoo HH. An LCA study of a primary aluminum supply chain. J Clean Prod 2005;13:607-18.

[77] Gulišija Z, Patarić A, Mihailović M. The possibility of increasing production efficiency of Al alloys applying electromagnetic field. Metalurgija 2011;50:253-6.

[78] Lela B, Musa A, Zovko O. Model-based controlling of extrusion process. Int J Adv Manuf Technol 2014;74:1267-73.

[79] Saha PK. Aluminum extrusion technology. Materials Park, Ohio: ASM International; 2000.

[80] Schmidt CW, Buchholz A, Karhausen KF. The importance of heat removal for productivity in industrial twin roll casting of aluminium. In: Hyland M, editor. Light metals 2015, Hoboken, New Jersey: John Wiley \& Sons, Inc.; 2015, p. 120913.

[81] Liu Y, Jiang D, Li B, Ying T, Hu J. Heating aging behavior of Al-8.35Zn-2.5Mg-2.25Cu alloy. Mater and Des 2014;60:116-24.

[82] Liu Y, Jiang D, Li B, Yang W, Hu J. Effect of cooling aging on microstructure and mechanical properties of an Al-Zn-Mg-Cu alloy. Mater and Des 2014;57:79-86.

[83] Kasprzak W, Sokolowski JH, Yamagata H, Aniolek M, Kurita H. Energy efficient heat treatment for linerless hypereutectic Al-Si engine blocks made using vacuum HPDC process. J Mater Eng Perform. 2011;20:120-32. 
[84] Choi J, Go BS, Kim SK, Cho SH, Park HJ, Moon HJ, et al. Economic feasibility study of an HTS DC induction furnace. IEEE Trans Appl Supercond 2016;26.

[85] Choi J, Kim SK, Kim S, Sim K, Park M, Yu IK. Simulation and experimental demonstration of a large-scale HTS AC induction furnace for practical design. IEEE Trans on Appl Superconductivity 2016;26.

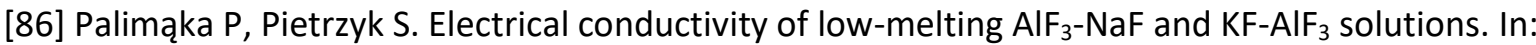
Tokarski T, editor. Key engineering materials, vol. 641, Zurich, Switzerland: Trans Tech Publications Ltd.; 2014, p. 169-72.

[87] Zheng Y, Peng C, Zheng $Y$, Tian D, Zuo Y. Low-temperature electrolysis of aluminium from 1butyl-3-methylimidazolium chloroaluminate ionic liquids with inert anode. Int J Electrochem Sci 2016;11:6095-109.

[88] Apisarov A, Dedyukhin A, Nikolaeva E, Tin'ghaev P, Tkacheva O, Redkin A, et al. Liquidus temperatures of cryolite melts with low cryolite ratio. In: Johnson, JA, editor. TMS Light metals 2010, Seattle, WA: Minerals, Metals and Materials Society; 2010, p. 395-8.

[89] Dedyukhin AE, Apisarov AP, Redkin AA, Tkacheva OY, Zaikov YP. Influence of CaF2 on the properties of the low-temperature electrolyte based on the KF-AIF3 ( $C R=1,3)$ system. In: DeYoung, DH, editor. TMS Light metals 2008, p. 509-11.

[90] Galasiu I, Galasiu R. Aluminium electrolysis with inert anodes and wettable cathodes and with low energy consumption. In: Gaune-Escard M, Haarberg GM, editors. Molten salts chemistry and technology, Chichester, England: Wiley and Sons; 2014.

[91] Redkin A, Apisarov A, Dedyukhin A, Kovrov V, Zaikov Y, Tkacheva O, et al. Recent developments in low-temperature electrolysis of aluminum. ECS Trans 2012;50:205-13.

[92] Pawlek RP. Wettable cathodes: an update. In Johnson, JA, editor. TMS Light metals 2010, Seattle, WA: Minerals, Metals and Materials Society; 2010, p. 377-82.

[93] Li J, Lü X-j, Lai Y-q, Li Q-y, Liu Y-x. Research progress in TiB2 wettable cathode for aluminum reduction. JOM 2008;60:32-7.

[94] Keniry J. The economics of inert anodes and wettable cathodes for aluminum reduction cells. JOM 2001;53:43-7.

[95] Heidari H, Alamdari H, Dubé D, Schulz R. Pressureless sintering of TiB2-based composites using Ti and Fe additives for development of wettable cathodes. In: Lindsay, SJ, editor. TMS Light metals 2011, Switzerland: Springer International Publishers; 2011, p. 1109-16.

[96] Heidari H. Development of wettable cathode for aluminum smelting. Québec City, Canada: University of Laval; 2012.

[97] Norgate T, Jahanshahi S. Reducing the greenhouse gas footprint of primary metal production: where should the focus be? Miner Eng 2011;24:1563-70.

[98] Wang Z, Rutlin J, Grande T. Sodium diffusion in cathode lining in aluminium electrolysis cells. In Johnson, JA, editor. TMS Light metals 2010, Seattle, WA: Minerals, Metals and Materials Society; 2010, p. 841-7.

[99] U.S. Aluminum Association. Inert anode roadmap. Washington, DC: U.S. Department of Energy; 1998.

[100] Wang D, Xiao W. Inert anode development for high-temperature molten salts. In: Lantelme, F, Groult, $\mathrm{H}$, editors. Molten salts chemistry: from lab to applications, Burlington \& San Diego, USA:

Elsevier Inc.; 2013, p. 171-86.

[101] Kvande $H$, Drabløs PA. The aluminum smelting process and innovative alternative technologies. J Occup Environ Med 2014;56:S23-S32.

[102] International Energy Agency. Energy technology perspectives 2008-scenarios and strategies to 2050. Paris: OECD/IEA; 2008.

[103] Kvande H, Haupin W. Inert anodes for Al smelters: energy balances and environmental impact. JOM 2001;53:29.

[104] Haarberg GM, Khalaghi B, Mokkelbost T. Natural gas anodes for aluminium electrolysis in molten fluorides. Faraday Discuss 2016;190:71-84. 
[105] Norgate TE, Jahanshahi S, Rankin WJ. Assessing the environmental impact of metal production processes. J Clean Prod 2007;15:838-48.

[106] Nightingale SA, Longbottom RJ, Monaghan BJ. Corrosion of nickel ferrite refractory by $\mathrm{Na}_{3} \mathrm{AlF}_{6}-$ $\mathrm{AlF}_{3}-\mathrm{CaF}_{2}-\mathrm{Al}_{2} \mathrm{O}_{3}$ bath. J Eur Ceram Soc 2013;33:2761-5.

[107] Rhamdhani MA, Dewan MA, Brooks GA, Monaghan BJ, Prentice L. Alternative Al production methods: part 1 - a review of indirect carbothermal routes. Trans of the Inst of Min and Metall, Sect C: Miner Process Extr Metall 2013;122:87-104.

[108] Liu D, Zhang G, Li J. Solid state carbothermal reduction of alumina. In: Bearne, G, editor. Light metals 2009, Warrendale: TMS; 2009; p. 429-34.

[109] Li J, Zhang G, Liu D, Ostrovski O. Low-temperature synthesis of aluminium carbide. ISIJ Int 2011;51:870-7.

[110] Kemper C, Friedrich B, Balomenos E, Panias D, Paspaliaris I. Thermodynamic analysis and experimental validation of carbothermically producing AlSi-alloy. European Metallurgical Conference, EMC 2013, p. 1027-32.

[111] Warner NA. Conceptual design for lower-energy primary aluminum. Metall Mater Trans B: Process Metall Mater Processing Sci 2008;39:246-67.

[112] Puig J, Balat-Pichelin M. Production of metallic nanopowders (Mg, Al) by solar carbothermal reduction of their oxides at low pressure. J Magnes Alloy 2016;4:140-50.

[113] Kruesi M, Galvez ME, Halmann M, Steinfeld A. Solar aluminum production by vacuum carbothermal reduction of alumina-thermodynamic and experimental analyses. Metall Mater Trans B: Process Metall Mater Processing Sci 2011;42:254-60.

[114] Xia D, Shang Y, Ren L. A comparative study on the separating methods of Al, Ca and Mg based on theoretical energy consumption. J Therm Sci 2011;20:82-7.

[115] Balomenos E, Panias D, Paspaliaris I. Energy and exergy analysis of the primary aluminum production processes: a review on current and future sustainability. Miner Process and Extr Metall Rev 2011;32:69-89.

[116] Musa C, Licheri R, Locci AM, Orrù R, Cao G, Rodriguez MA, et al. Energy efficiency during conventional and novel sintering processes: the case of $\mathrm{Ti}^{-} \mathrm{Al}_{2} \mathrm{O}_{3}-\mathrm{TiC}$ composites. J Clean Prod 2009;17:877-82.

[117] Zeng B, Jolly M, Dai X. Designing novel CRIMSON running system through numerical simulation method for the purpose of reducing the energy content of aluminium investment casting. In: Pati $S$, Drelich J, Jha A, Neelameggham N, Prentice L, Wang C, editors. Energy technology 2013: carbon dioxide management and other technologies, San Antonio, USA: John Wiley \& Sons, Inc.; 2013. [118] Jolly M, Dai X. Energy efficiency improvement by implementation of the novel CRIMSON aluminium casting process. In: Neelameggham NR, Belt CK, Jolly M, Reddy RG, Yurko JA, editors. Energy technology 2011: Carbon dioxide and other greenhouse gas reduction metallurgy and waste heat recovery, Hoboken, New Jersey: John Wiley \& Sons Inc.; 2011, p. 55-64.

[119] Dai X, Jolly M, Zhang B. Reduction of energy consumption and GHGs emission in investment casting process by application of a new casting method. In: Salazar-Villalpando MD, Neelameggham NR, Post Guillen D, Pati S, Krumdick GK, editors. Energy technology 2012: carbon dioxide management and other technologies, Hoboken, New Jersey: John Wiley \& Sons Inc.; 2012, p. 15-22. [120] Belov NA, Alabin AN. Energy efficient technology for Al-Cu-Mn-Zr sheet alloys. In: Materials Science Forum, editor. 6th International Light Metals Technology Conference, Old Windsor, United Kingdom: Trans Tech Publications, Switzerland; 2013, p. 13-7.

[121] Belov NA, Alabin AN, Matveeva IA. Optimization of phase composition of Al-Cu-Mn-Zr-Sc alloys for rolled products without requirement for solution treatment and quenching. J Alloy Compds 2014;583:206-13.

[122] International Energy Agency (IEA). Energy technology transitions for industry: strategies for the next industrial revolution, Paris: OECD Publishing; 2009. 
[123] Tian Z, Lai Y, Yang S, Li J, Hwang JY, Liu Y. Anodic corrosion behavior of $\mathrm{NiFe}_{2} \mathrm{O}_{4}$-Based Cermet in $\mathrm{Na}_{3} \mathrm{AlF}_{6}-\mathrm{K}_{3} \mathrm{AlF}_{6}-\mathrm{AlF}_{3}$ for aluminum electrolysis. Metall Mater Trans B: Process Metall Mater Proc Sci 2015;46:1257-61.

[124] Tkacheva O, Spangenberger J, Davis B, Hryn J. Aluminum electrolysis in an inert anode cell. Molten Salts Chem Technol; 2014, p. 53-69.

[125] Sadoway DR. Inert anodes for the Hall-Héroult cell: the ultimate materials challenge. JOM 2001;53:34-5.

[126] Ding H, Lu S, Kan S, Zhang X, Yang J. NiFe alloy anode for aluminum electrolysis in low temperature electrolyte system. Xiyou Jinshu/Chin J Rare Met 2011;35:72-7.

[127] Goupil G, Helle S, Davis B, Guay D, Roué L. Anodic behavior of mechanically alloyed Cu-Ni-Fe and $\mathrm{Cu}$-Ni-Fe-O electrodes for aluminum electrolysis in low-temperature $\mathrm{KF}^{-\mathrm{AlF}_{3}}$ electrolyte.

Electrochim Acta 2013;112:176-82.

[128] Wang J, Lai Y, Tian Z, Li J, Liu Y. Investigation of 5Cu-(10NiO-NiFe2O4) inert anode corrosion during low-temperature aluminum electrolysis. In: Sorlie M, editor. Light metals 2007, volume 2, aluminium reduction, Hoboken, New Jersey: John Wiley \& Sons, Inc.; p. 525-30.

[129] Wang G, Sun X. Electrochemical behavior of cermet anodes in Na3AlF 6-K3AlF6-based lowmelting electrolytes for aluminium electrolysis. TMS Light metals. Light Metals 2013 - At the TMS 2013 Annual Meeting and Exhibition; 2013, p. 1295-8.

[130] Wang G, Sun X, Wang W, Wang D, He Y. Corrosion behavior of cermet anodes in Na3AlF6K3AIF6-based baths for low-temperature aluminum electrolysis cells. In: TMS 2011 140th Annual Meeting \& Exhibition, Volume 3: General Paper Selections, Hoboken, New Jersey: John Wiley \& Sons Inc.; 2011, p. 175-82.

[131] Khramov AP, Kovrov VA, Zaikov YP, Chumarev VM. Anodic behaviour of the Cu82Al8Ni5Fe5 alloy in low-temperature aluminium electrolysis. Corros Sci 2013;70:194-202.

[132] Ding HS, Guo JJ, Jia J, Bi WS, Chen L. Mould filling ability and microstructure of aluminum alloy under electromagnetic die casting. Trans Nonferrous Met Soc China (Engl Ed) 2001;11:540-6.

[133] Zhu Q, Zhao Z, Wang X, Cui J. The effect of Al-5Ti-1B and combination electromagnetic field on grain evolution of die casting commercial aluminum. In: Jiang Z, Zhang C, editors. Adv Mater Res, vols 97-101, Zurich: Trans Tech Publications Inc.; 2010, p. 975-8.

[134] Benedyk J. International temper designation systems for wrought aluminum alloys: part II thermally treated (T temper) aluminum alloys. Light Metal Age. 2010;68:16-22.

[135] Broberg Viklund S, Johansson MT. Technologies for utilization of industrial excess heat:

potentials for energy recovery and $\mathrm{CO}_{2}$ emission reduction. Energy Conversion and Management 2014;77:369-379.

[136] Satyendra. Argon rinsing of steels. http://ispatguru.com/argon-rinsing-of-steels/; 26 October 2014 [accessed 17.06.13].

[137] Brown C. Next generation vertical electrode cells. JOM. 2001;53:39-42.

[138] dmitri_kopeliovich. Metals. http://www.substech.com/dokuwiki/doku.php?id=metals; 5 January 2013 [accessed 17.06.15]. 